Keywords: Hazardous Sludge Simulants, Enhanced Chemical Cleaning

Retention: Permanent

\title{
Development of Hazardous Sludge Simulants for Enhanced Chemical Cleaning Tests
}

Russell E. Eibling

April 2010

Savannah River National Laboratory Savannah River Nuclear Solutions Aiken, SC 29808

Prepared for the U.S. Department of Energy under contract number DE-AC09-08SR22470.

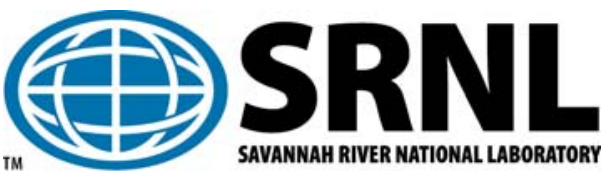


SRNL-STI-2010-00170

Revision 0

\section{DISCLAIMER}

This work was prepared under an agreement with and funded by the U.S. Government. Neither the U.S. Government or its employees, nor any of its contractors, subcontractors or their employees, makes any express or implied:

1. warranty or assumes any legal liability for the accuracy, completeness, or for the use or results of such use of any information, product, or process disclosed; or

2. representation that such use or results of such use would not infringe privately owned rights; or

3. endorsement or recommendation of any specifically identified commercial product, process, or service.

Any views and opinions of authors expressed in this work do not necessarily state or reflect those of the United States Government, or its contractors, or subcontractors.

\section{Printed in the United States of America \\ Prepared for \\ U.S. Department of Energy}




\section{REVIEWS AND APPROVALS}

\section{AUTHORS:}

R. E. Eibling, Engineering Process Development

Date

TECHNICAL REVIEW:

C. J. Martino, Advanced Characterization \& Process

Date

APPROVAL:

A. B. Barnes, Manager

Date

Engineering Process Development

F. M. Pennebaker, Manager

Date

Advanced Characterization \& Process

S. L. Marra, Manager

Date

Environmental \& Chemical Process Technology Research Programs

R. H. Spires, Project Manager

Date

Closure Projects, Savannah River Remediation 


\section{ACKNOWLEDGEMENTS}

The research discussed in this report was aided by technical discussions with C. J. Martino, W. D. King, M. S. Hay, M. R. Poirier and M. R. Williams. Laboratory assistance was provided by J. W. Duvall, M. F. Williams and V. J. Williams. 


\section{EXECUTIVE SUMMARY}

Savannah River Remediation has requested the Savannah River National Laboratory to develop and produce three new sludge simulants that are resistant to oxalic acid dissolution and contain RCRA hazardous metals for use in additional planned Enhanced Chemical Cleaning process tests. The results of the simulant development are:

- The development and production of lab-scale quantities of the Purex, HM and Blend simulants has been completed.

- The hazardous metals in the new simulants are mercury, silver, barium, cadmium, chromium and lead with the mercury present at HM waste levels in all three simulants.

- The resistance of the three simulants to oxalic acid is similar to or more resistant than actual radioactive waste in prior lab and plant tests.

- The minimum amount of one weight percent oxalic acid required to adjust the $\mathrm{pH}$ of the three new simulants was determined to be from 12 to 16.4 times the volume of decanted simulant.

- At the minimum acid quantity, the simulant $\mathrm{pH}$ will tend to drift above $\mathrm{pH} 2$ due to the slow reaction kinetics of the acid reactive sludge solids. Addition of more acid over time will be required to maintain a pH below 2 .

- Sufficient quantities of each simulant were prepared for use in corrosion testing as requested by SRR.

Any additional improvement in the simulant properties with respect to actual waste using the approach applied to the current simulants will require more detailed information about the specific compounds present in actual radioactive sludge. Such information may provide alternative choices for the mineral phases that could be used in the production of simulants to represent the sludge heels in high level waste tanks to be closed. 


\section{TABLE OF CONTENTS}

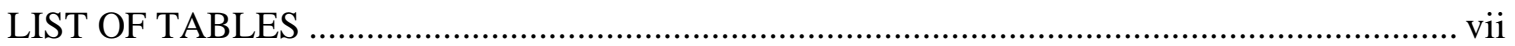

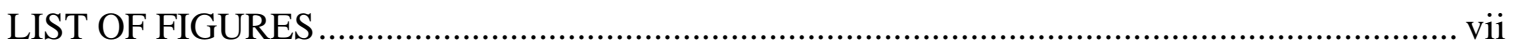

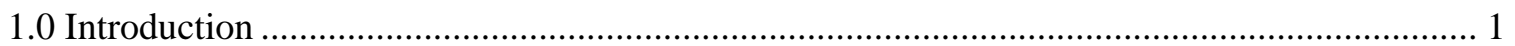

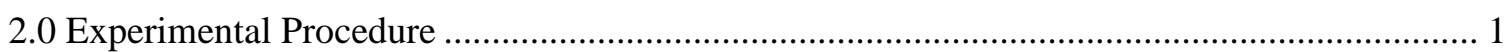

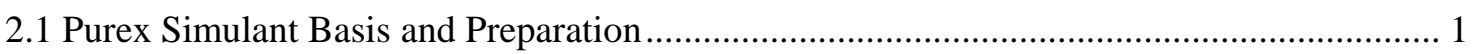

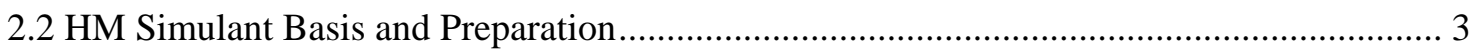

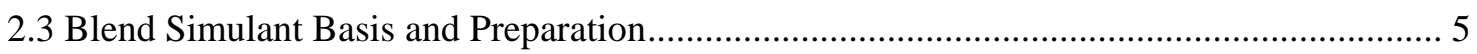

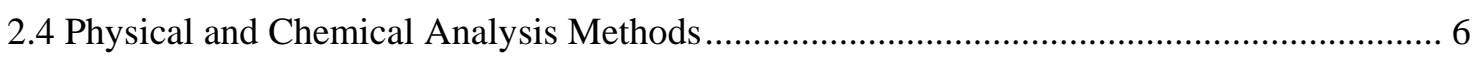

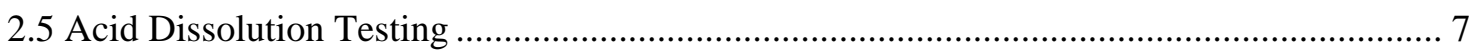

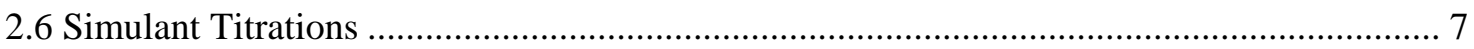

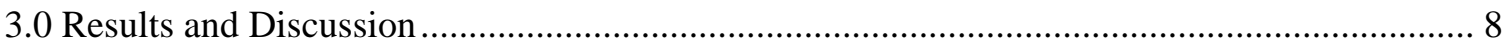

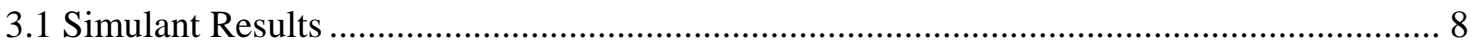

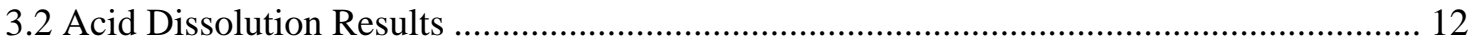

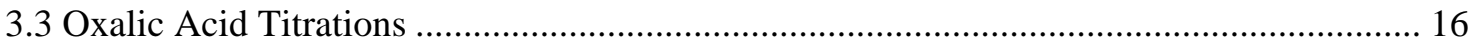

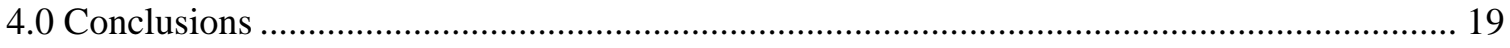

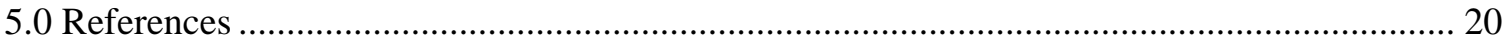

Appendix A: ECC Purex Hazardous Sludge Simulant Recipe.................................................... 21

Appendix B: ECC HM Hazardous Sludge Simulant Recipe........................................................ 26

Appendix C: ECC Blend Hazardous Sludge Simulant Recipe.................................................... 31 


\section{LIST OF TABLES}

Table 2-1. Purex Hazardous ECC Sludge Simulant Basis ........................................................... 2

Table 2-2. HM Hazardous ECC Sludge Simulant Basis ............................................................... 3

Table 2-3. Blend (Purex+HM) Hazardous ECC Sludge Simulant Basis....................................... 5

Table 3-1. Physical Properties of Purex ECC Sludge Simulant ................................................... 8

Table 3-2. Purex Hazardous ECC Sludge Simulant Composition ............................................. 9

Table 3-3. Physical Properties of HM ECC Sludge Simulant ...................................................... 10

Table 3-4. HM Hazardous ECC Sludge Simulant Composition ............................................... 10

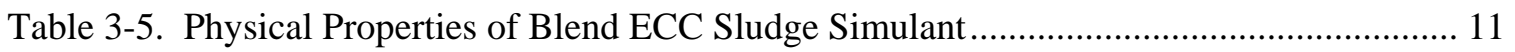

Table 3-6. Blend Hazardous ECC Sludge Simulant Composition .............................................. 11

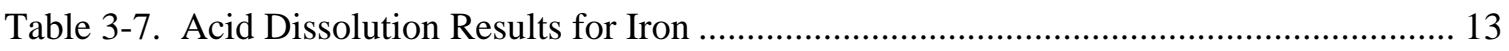

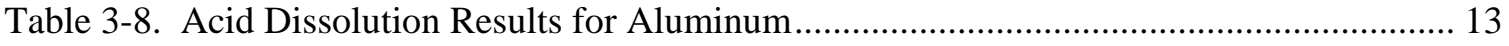

Table 3-9. Acid Dissolution Results for Manganese .................................................................... 14

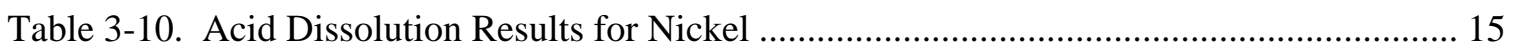

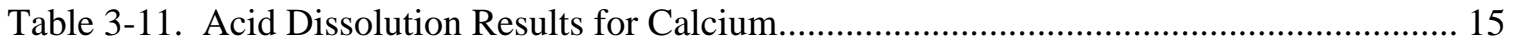

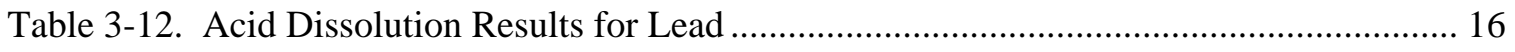

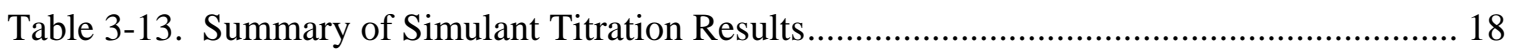

Table 3-14. Stability of pH for Acid Adjusted Simulants ........................................................... 19

\section{LIST OF FIGURES}

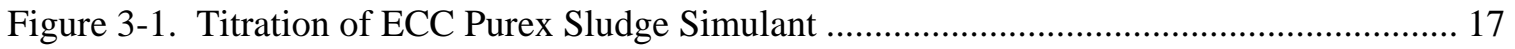

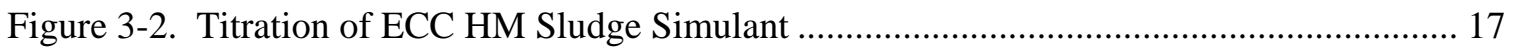

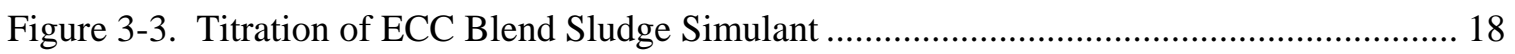




\section{LIST OF ABBREVIATIONS}

$\begin{array}{ll}\text { AOP } & \text { Advanced Oxidative Process } \\ \text { DI } & \text { Deionized } \\ \text { ECC } & \text { Enhanced Chemical Cleaning } \\ \text { ICPES } & \text { Inductively Coupled Plasma Emission Spectrophotometer } \\ \text { ISFET } & \text { Ion Sensitive Field Effect Transistor } \\ \text { RCRA } & \text { Resource Conservation and Recovery Act } \\ \text { SRNL } & \text { Savannah River National Laboratory } \\ \text { SRR } & \text { Savannah River Remediation }\end{array}$




\subsection{Introduction}

An Enhanced Chemical Cleaning (ECC) process is being developed by Savannah River Remediation (SRR) to aid in Savannah River Site (SRS) High-Level Waste (HLW) tank closure. After bulk waste removal, the ECC process can be used to dissolve and remove much of the remaining sludge from HLW tanks. The ECC process uses dilute oxalic acid (1 wt \%) with inline $\mathrm{pH}$ monitoring and control. The resulting oxalate is decomposed through hydroxylation using an Advanced Oxidation Process (AOP). Minimizing the amount of oxalic acid used for dissolution and the subsequent oxidative destruction of oxalic acid will minimize the potential for downstream impacts. Initial efficacy tests by AREVA demonstrated that previous tank heel simulants could be dissolved using dilute oxalic acid. The oxalate could be decomposed by an AOP that utilized ozone and ultraviolet (UV) light, and the resultant metal oxides and hydroxides could be separated out of the process. ${ }^{1}$

Additional testing of the AOP process by AREVA is required by SRR to evaluate the impact of undissolved sludge solids and redox active metals on the proposed process. Prior tests used a Purex simulant that dissolved too easily and did not include hazardous metals. A technical task request from SRR asked SRNL to develop and produce three sludge simulants that were more resistant to oxalic acid dissolution and contained the hazardous (as defined by RCRA) metals. ${ }^{2}$ The simulants to be developed were a Purex simulant, a HM Simulant and a blend simulant. This report describes the development of the simulants, acid dissolution tests, production of the simulants to support corrosion tests and documents the final recipes for the simulants.

\subsection{Experimental Procedure}

\subsection{Purex Simulant Basis and Preparation}

Sludge simulants can be produced by precipitation in the same manner in which the bulk of the SRS sludge was originally generated or by addition of oxides, hydroxides or typical waste species. The ECC Purex hazardous sludge simulant was prepared in the same manner as previous SRS simulants with modifications to improve resistance to acid dissolution. The simulant preparation process consists of the following steps:

1. Generation of hydrated manganese dioxide by reacting manganous nitrate with potassium permanganate at $40^{\circ} \mathrm{C}$ while mixing.

2. Addition of the following transition and lanthanide metal nitrates while maintaining mixing to allow dissolution of the salts: Ferric nitrate, nickel nitrate, cerium nitrate, lanthanum nitrate, silver nitrate and cadmium nitrate.

3. Precipitation of the transition and lanthanide metals with sodium hydroxide by raising the $\mathrm{pH}$ to 10.

4. Washing the excess sodium nitrate from the precipitated solids using inhibited wash water (0.001 molar in sodium hydroxide and 0.001 molar in sodium nitrite) until the nitrate concentration is less than one gram per liter.

5. Thermally aging the precipitated solids by heating to $95^{\circ} \mathrm{C}$ while mixing for a period of 24 hours.

6. Addition of the final insoluble solids and soluble salts to match the desired sludge basis composition.

To improve the acid dissolution resistance of the final sludge simulant a portion of the iron and aluminum were added as specific oxides (hematite and alumina). 
The compositional basis of the Purex sludge simulant was derived from the same basis used for the simulant in prior acid cleaning tests (Tank 8F sludge) to provide both a link and a contrast to the prior simulant. The ECC hazardous Purex sludge simulant uses the same basis ${ }^{3}$ as the previously tested simulant modified by results from an analysis of a sample ${ }^{4}$ of Tank $8 \mathrm{~F}$. The hazardous metals were added at the level observed for Purex waste except for mercury which was added at the same level as observed in the HM sludge basis as requested by SRR. The analytical basis for the Purex simulant is show in Table 2-1.

Table 2-1. Purex Hazardous ECC Sludge Simulant Basis

\begin{tabular}{|c|c|c|}
\hline Analyte & wt \% Total Solids & grams/Liter \\
\hline $\mathrm{Ag}$ & 0.0154 & 0.03 \\
\hline $\mathrm{Al}$ & 8.22 & 15.79 \\
\hline $\mathrm{Ba}$ & 0.22 & 0.423 \\
\hline $\mathrm{Ca}$ & 1.938 & 3.72 \\
\hline $\mathrm{Cd}$ & 0.0062 & 0.012 \\
\hline$\overline{\mathrm{Ce}}$ & 0.22 & 0.42 \\
\hline $\mathrm{Cl}^{-}$ & 0.9 & 1.73 \\
\hline $\mathrm{CO}_{3}^{-2}$ & 4.103 & 7.88 \\
\hline $\mathrm{Cr}$ & 0.22 & 0.422 \\
\hline $\mathrm{Cu}$ & 0.12 & 0.23 \\
\hline $\mathrm{F}^{-}$ & 0.0086 & 0.017 \\
\hline $\mathrm{Fe}$ & 22.27 & 42.77 \\
\hline $\mathrm{Hg}$ & 1.01 & 1.94 \\
\hline $\mathrm{I}^{-}$ & 0.022 & 0.042 \\
\hline $\mathrm{K}$ & 0.03 & 0.058 \\
\hline $\mathrm{La}$ & 0.13 & 0.25 \\
\hline $\mathrm{Li}$ & 0.0627 & 0.12 \\
\hline $\mathrm{Mg}$ & 0.11 & 0.21 \\
\hline Mn & 2.5 & 4.8 \\
\hline $\mathrm{Na}$ & 6.594 & 12.66 \\
\hline $\mathrm{Ni}$ & 2.55 & 4.9 \\
\hline $\mathrm{NO}_{2}^{-}$ & 5.19 & 9.97 \\
\hline $\mathrm{NO}_{3}^{-}$ & 1.167 & 2.24 \\
\hline $\mathrm{OH}^{-}$ & 1.29 & 2.48 \\
\hline $\mathrm{Pb}$ & 0.09 & 0.17 \\
\hline $\mathrm{PO}_{4}^{-3}$ & 0.141 & 0.27 \\
\hline $\mathrm{Si}$ & 0.7 & 1.34 \\
\hline $\mathrm{SO}_{4}^{-2}$ & 0.763 & 1.47 \\
\hline
\end{tabular}




\begin{tabular}{|c|c|c|}
\hline Analyte & wt \% Total Solids & grams/Liter \\
\hline \hline $\mathrm{Sr}$ & 0.077 & 0.15 \\
\hline $\mathrm{Zn}$ & 0.24 & 0.46 \\
\hline $\mathrm{Zr}$ & 0.44 & 0.85 \\
\hline \hline Wt \% Total Solids & 16.70 & \multicolumn{1}{|}{} \\
\hline \hline Density, grams/mL & 1.15 & \multicolumn{1}{|c}{} \\
\hline
\end{tabular}

The complete recipe for the ECC Purex hazardous sludge simulant is given in Appendix A.

\subsection{HM Simulant Basis and Preparation}

The HM sludge simulant was based on recent samples obtained for actual Tank $12 \mathrm{H}$ sludge $\mathrm{e}^{5,6}$ that were collected prior to transfer to Tank $51 \mathrm{H}$ for aluminum dissolution. The starting basis for the simulant is show in Table 2-2. This simulant preparation was designed to minimize the need for washing during production of the simulant. Therefore, the soluble species (hydroxide, nitrate, nitrite, chloride, sulfate, phosphate) were adjusted to represent a partial wash of the sludge since the actual sludge samples represented unwashed sludge. The concentrations for the hazardous metals in the HM simulant were set to the same level as in the Purex simulant by request of SRR.

Table 2-2. HM Hazardous ECC Sludge Simulant Basis

\begin{tabular}{|c|c|c|}
\hline Analyte & $\begin{array}{c}\text { wt \% Total } \\
\text { Solids }\end{array}$ & grams/Liter \\
\hline $\mathrm{Ag}$ & 0.006 & 0.032 \\
\hline Al (soluble) & 0.71 & 3.72 \\
\hline $\mathrm{Al}$ (insoluble) & 9.1 & 47.67 \\
\hline B & 0.009 & 0.047 \\
\hline $\mathrm{Ba}$ & 0.085 & 0.446 \\
\hline $\mathrm{C}_{2} \mathrm{O}_{4}{ }^{-2}$ & 0.042 & 0.22 \\
\hline $\mathrm{Ca}$ & 0.22 & 1.15 \\
\hline $\mathrm{Cd}$ & 0.0024 & 0.013 \\
\hline $\mathrm{Ce}$ & 0.021 & 0.11 \\
\hline $\mathrm{Cl}^{-}$ & 0.06 & 0.31 \\
\hline $\mathrm{CO}_{3}^{-2}$ & 9.51 & 49.8 \\
\hline $\mathrm{Cr}$ & 0.086 & 0.45 \\
\hline $\mathrm{Cu}$ & 0.01 & 0.052 \\
\hline $\mathrm{F}^{-}$ & 0.02 & 0.11 \\
\hline $\mathrm{Fe}$ & 1 & 5.24 \\
\hline $\mathrm{Hg}$ & 0.39 & 2.04 \\
\hline $\mathrm{K}$ & 0.045 & 0.24 \\
\hline $\mathrm{La}$ & 0.011 & 0.06 \\
\hline $\mathrm{Li}$ & 0.025 & 0.13 \\
\hline $\mathrm{Mg}$ & 0.21 & 1.1 \\
\hline
\end{tabular}


SRNL-STI-2010-00170

Revision 0

\begin{tabular}{|c|c|c|}
\hline Analyte & $\begin{array}{c}\text { wt \% Total } \\
\text { Solids } \\
\end{array}$ & grams/Liter \\
\hline $\mathrm{Mn}$ & 0.98 & 5.11 \\
\hline Mo & 0.005 & 0.024 \\
\hline $\mathrm{Na}$ & 10.8 & 56.6 \\
\hline $\mathrm{Nd}$ & 0.005 & 0.03 \\
\hline $\mathrm{Ni}$ & 0.12 & 0.63 \\
\hline $\mathrm{NO}_{2}^{-}$ & 1.1 & 5.73 \\
\hline $\mathrm{NO}_{3}{ }^{-}$ & 6.15 & 32.23 \\
\hline $\mathrm{OH}^{-}$ & 0.35 & 1.84 \\
\hline $\mathrm{Pb}$ & 0.04 & 0.18 \\
\hline $\mathrm{PO}_{4}^{-3}$ & 0.02 & 0.1 \\
\hline $\mathrm{Si}$ & 0.04 & 0.21 \\
\hline $\mathrm{SO}_{4}^{-2}$ & 0.33 & 1.73 \\
\hline $\mathrm{Sr}$ & 0.0069 & 0.036 \\
\hline $\mathrm{Ti}$ & 0.0029 & 0.02 \\
\hline $\mathrm{Zn}$ & 0.014 & 0.073 \\
\hline $\mathrm{Zr}$ & 0.044 & 0.23 \\
\hline Wt\% Solids & 38.8 & \\
\hline Density, g/mL & 1.35 & \\
\hline
\end{tabular}

The steps in producing the HM hazardous sludge simulant are:

1. Generation of hydrated manganese dioxide by reacting manganous nitrate with potassium permanganate at $40{ }^{\circ} \mathrm{C}$ while mixing.

2. Addition of the following transition metal nitrates, lanthanide nitrates and soluble salts while maintaining mixing to allow dissolution of the salts: ferric nitrate, ferric oxide, nickel nitrate, zirconyl nitrate, cerium nitrate, lanthanum nitrate, barium nitrate, cupric nitrate, magnesium nitrate, lead nitrate, zinc nitrate, silver nitrate, neodymium nitrate, cadmium nitrate, chromium nitrate, boric acid, sodium fluoride, sodium chloride, sodium sulfate sodium phosphate, and potassium molybdate.

3. Precipitation of the transition and lanthanide metals with sodium hydroxide by raising the $\mathrm{pH}$ to 10.

4. Add sodium aluminate and sodium metasilicate to allow the potential generation of aluminosilicates.

5. Thermally aging the precipitated solids by heating to $95{ }^{\circ} \mathrm{C}$ while mixing for a period of 24 hours.

6. Add the acid-reactive salts (sodium oxalate, sodium carbonate and sodium nitrite) to allow conversion of some more soluble oxides in to lower soluble carbonates and oxalates,

7. Add the final insoluble compounds (aluminum oxide, aluminum hydroxide and titanium dioxide) other than mercury to the simulant.

8. Finally add mercuric nitrate plus additional sodium hydroxide and lithium hydroxide to generate mercuric oxide dispersed in the simulant. 
After completion of the initial test simulants, SRR requested that an additional washing step be performed on the HM simulant to further reduce the hydroxide content of the simulant. Therefore, a decant of supernate, followed by a single stage of wash/decant/dilution was added between steps 7 and 8 to minimize mercury losses and also the volume of hazardous wash water for disposal. The final complete HM simulant recipe is shown in Appendix B.

\subsection{Blend Simulant Basis and Preparation}

The Blend simulant represents an equal volume blend of Purex sludge and HM sludge. The basis for the simulant was obtained by combining the concentration of the nonhazardous, insoluble species from both simulants and dividing by two. The hazardous species were set to be equivalent to the level in both simulants. The basis for the Blend simulant is shown in Table 2-3. The simulant preparation method is the same as the HM simulant listed above. The recipe for the simulant is listed in Appendix C.

Table 2-3. Blend (Purex+HM) Hazardous ECC Sludge Simulant Basis

\begin{tabular}{|c||c||c||}
\hline Analyte & $\begin{array}{c}\text { wt \% Total } \\
\text { Solids }\end{array}$ & grams/Liter \\
\hline \hline $\mathrm{Ag}$ & 0.009 & 0.03 \\
\hline \hline $\mathrm{Al}$ (soluble) & 1.704 & 5.71 \\
\hline \hline $\begin{array}{c}\mathrm{Al} \\
\text { (insoluble) }\end{array}$ & 11.226 & 37.606 \\
\hline \hline $\mathrm{B}$ & 0.014 & 0.047 \\
\hline \hline $\mathrm{Ba}$ & 0.129 & 0.432 \\
\hline \hline $\mathrm{C}_{2} \mathrm{O}_{4}{ }^{-2}$ & 0.088 & 0.294 \\
\hline \hline $\mathrm{Ca}$ & 1.14 & 3.82 \\
\hline \hline $\mathrm{Cd}$ & 0.004 & 0.012 \\
\hline \hline $\mathrm{Ce}$ & 0.033 & 0.11 \\
\hline \hline $\mathrm{Cl}{ }^{-}$ & 1.17 & 3.92 \\
\hline \hline $\mathrm{CO}{ }^{-2}$ & 11.9 & 39.85 \\
\hline \hline $\mathrm{Cr}$ & 0.13 & 0.44 \\
\hline $\mathrm{Cu}$ & 0.068 & 0.23 \\
\hline \hline $\mathrm{F}^{-}$ & 0.049 & 0.17 \\
\hline \hline $\mathrm{Fe}$ & 11.92 & 39.92 \\
\hline \hline $\mathrm{Hg}$ & 0.6 & 2.01 \\
\hline \hline $\mathrm{K}$ & 0.07 & 0.24 \\
\hline \hline $\mathrm{La}$ & 0.017 & 0.058 \\
\hline \hline $\mathrm{Li}$ & 0.037 & 0.125 \\
\hline \hline $\mathrm{Mg}$ & 0.22 & 0.74 \\
\hline \hline $\mathrm{Mn}$ & 1.48 & 4.95 \\
\hline $\mathrm{Mo}$ & 0.0001 & 0.024 \\
\hline $\mathrm{Na}$ & 24.53 & 82.17 \\
\hline
\end{tabular}


SRNL-STI-2010-00170

Revision 0

\begin{tabular}{|c|c|c|}
\hline Analyte & $\begin{array}{c}\text { wt \% Total } \\
\text { Solids } \\
\end{array}$ & grams/Liter \\
\hline $\mathrm{Nd}$ & 0.008 & 0.028 \\
\hline $\mathrm{Ni}$ & 1.37 & 4.59 \\
\hline $\mathrm{NO}_{2}{ }^{-}$ & 2.305 & 7.72 \\
\hline $\mathrm{NO}_{3}{ }^{-}$ & 2.95 & 9.89 \\
\hline $\mathrm{OH}^{-}$ & 0.74 & 2.48 \\
\hline $\mathrm{Pb}$ & 0.053 & 0.18 \\
\hline $\mathrm{PO}_{4}^{-3}$ & 0.22 & 0.72 \\
\hline Si & 0.7 & 2.35 \\
\hline $\mathrm{SO}_{4}^{-2}$ & 0.79 & 2.66 \\
\hline $\mathrm{Sr}$ & 0.077 & 0.26 \\
\hline $\mathrm{Ti}$ & 0.005 & 0.015 \\
\hline $\mathrm{Zn}$ & 0.13 & 0.44 \\
\hline $\mathrm{Zr}$ & 0.25 & 0.85 \\
\hline $\begin{array}{l}\text { Wt\% Total } \\
\text { Solids } \\
\end{array}$ & 26.8 & \\
\hline $\begin{array}{c}\text { Density, } \\
\text { g/mL }\end{array}$ & 1.25 & \\
\hline
\end{tabular}

\subsection{Physical and Chemical Analysis Methods}

The weight percent solids were determined using a Mettler Toledo HR73P Halogen Moisture Analyzer. The HR73P is programmed to heat the sample to $105{ }^{\circ} \mathrm{C}$ and monitor the mass of the sample until the change in mass is less than or equal to $1 \mathrm{mg}$ over a period of 130 seconds. The advantage of this method is that weight percent solids analysis can be performed in less than 20 minutes while a complete analysis of total solids in the sludge and dissolved solids in the supernate can take less than an hour. The homogenous sample (slurry or liquid) is placed on a glass fiber pad and the pad placed in the HR73P. The HR73P weighs the sample. The initial mass of the sample is the total mass $\left(\mathrm{m}_{\mathrm{tt}}\right)$. The sample is then heated by the infrared radiation from a Halogen lamp to $105{ }^{\circ} \mathrm{C}$ (controlled by a thermocouple) to drive off all the water (assuming mass loss is only from water) and the resulting remaining mass is the total solids $\left(\mathrm{m}_{\mathrm{ts}}\right)$ in the sample. The weight percent (wt \%) total solids (TS) of the sludge was determined using equation [1].

$$
w t \%_{t s}=\frac{m_{t s}}{m_{t t}} \times 100 \%
$$

A sample of the slurry is centrifuged (at 4332 gravities) to obtain the supernate. The resulting supernate is then processed through a $0.45 \mu \mathrm{m}$ filter. A sample of the filtered supernate is then placed on a glass fiber pad, placed in the HR73P, and weighed. The mass of sample used is the total mass of the supernate $\left(\mathrm{m}_{\mathrm{st}}\right)$. The sample is then heated by the Halogen lamp to $105{ }^{\circ} \mathrm{C}$ to drive off all the water and the resulting remaining mass is the total dissolved solids $\left(\mathrm{m}_{\mathrm{ds}}\right)$ in the supernate. The weight percent of total dissolved solids (DS) in the supernate is determined using equation [2]. This analysis assumes that all the solids in the resulting supernate are dissolved. 
SRNL-STI-2010-00170

Revision 0

$$
w t \%_{d s}=\frac{m_{d s}}{m_{s t}} \times 100 \%
$$

The weight percent of insoluble solids (IS) and soluble solids (SS) of the slurry are then calculated by the following conservation of mass relationships, equations [3] and [4] respectively.

$$
\begin{gathered}
w t \%_{i s}=\frac{w t \%_{t s}-w t \%_{d s}}{100 \%-w t \%_{d s}} \times 100 \% \\
w t \%_{s s}=w t \%_{t s}-w t \%_{i s}
\end{gathered}
$$

Density was determined using an Anton Paar DMA 4500 density meter. The density meter determines the density of a sample by measuring the resonant frequency of a sample-filled U tube at a specified temperature. Additional confirmation of simulant density was obtained by filling a tared $10 \mathrm{~mL}$ Class A volumetric flask to the mark and weighing the flask on an analytical balance on an as needed basis.

\subsection{Acid Dissolution Testing}

The resistance of each of the simulants to acid dissolution was tested using one weight percent oxalic acid ( 0.11 molar), or 0.11 molar nitric acid, or 0.11 molar sulfuric acid. To minimize the impact of the base on the supernate phase, each simulant was centrifuged and the supernate decanted from the sludge solids. The solid phase was mixed by stirring with a spatula and then 0.5 gram portions of the solid were added to labeled, tared $60 \mathrm{~mL}$ polypropylene wide mouth vials. In addition, a 0.5 gram portion of the ferric oxide and a 0.5 gram portion of the aluminum oxide were also prepared to test the reagent oxide resistance to acid dissolution. Next, 50 gram portions of one of the three acids were added to the vials (100:1 acid:sludge ratio). The vials were then placed in a New Brunswick C24 Incubator Shaker and shaken at 120 rpm while maintaining the temperature at $25^{\circ} \mathrm{C}$. The dissolution test duration was seven days after which a portion of the supernate was filtered through a 0.2 micron filter and submitted for analysis by ICPES for $\mathrm{Al}, \mathrm{Fe}, \mathrm{Ca}, \mathrm{Mg}, \mathrm{Mn}, \mathrm{Ni}$ and $\mathrm{Pb}$. A separate portion of each simulant was prepared in a similar manner and the solids analyzed for the initial content for each of the same elements. After the tests were completed, the $\mathrm{pH}$ of each of the test vessels were verified to be below $\mathrm{pH} 2$ by measuring the $\mathrm{pH}$ with an IQ Scientific Instruments IQ150 $\mathrm{pH}$ meter and an Ion Sensitive Field Effect Transistor (ISFET) $\mathrm{pH}$ probe. Calibration of the meter was performed using buffers at $\mathrm{pH}$ 4, 7 and 10 buffers.

\section{6 $\underline{\text { Simulant Titrations }}$}

A portion of each of the three simulants was titrated with $1 \mathrm{wt} \%$ oxalic acid to determine the minimum volume ratio of acid to add to a settled portion of the sludge simulant to produce a $\mathrm{pH}$ less than 2 to support corrosion testing and SRR planned tests. A $200 \mathrm{~mL}$ portion of the sludge simulant was allowed to settle for 24 hours so that the settled volume is $40 \%$ or less of the total. One hundred $\mathrm{mL}$ of supernate was removed and the remaining portions of the simulant mixed and transferred to a glass beaker (500 to $1000 \mathrm{~mL}$ ) for titration. A magnetic stir bar is added and the beaker placed on a Torrey Pines Scientific HS40 digital stirring hotplate. A platinum RTD temperature probe is inserted in the slurry and the target temperature of the slurry set to $40{ }^{\circ} \mathrm{C}$. An ISFET $\mathrm{pH}$ probe is inserted and the $\mathrm{pH}$ measured with a $\mathrm{pH}$ meter. Calibration of the meter was performed using buffers at $\mathrm{pH} \mathrm{4,7}$ and 10 buffers. Periodically, the probe is cleaned to 
prevent adhering sludge particles from interfering with the sensor operation. Mixing is started and once the temperature reaches the target, periodic additions of oxalic acid are made. Due to the slow kinetics of solids dissolution, each addition of acid and measurement of $\mathrm{pH}$ takes 5 to 20 minutes for the $\mathrm{pH}$ reading to stabilize.

\subsection{Results and Discussion}

\subsection{Simulant Results}

The goal of the ECC hazardous simulant development program was to produce sludge simulants that have resistance to acid dissolution similar to that observed with actual sludge retrieved from the tank farm. The normal approach to produce an SRS sludge simulant is to precipitate the iron, manganese and nickel in the same manner that the original waste was generated. Next Gibbsite $\left(\mathrm{Al}(\mathrm{OH})_{3}\right)$ and sometimes Boehmite $(\mathrm{AlOOH}$, if available) is added along with the remaining metals as oxides, carbonates phosphates and sulfates. Alternatively, the Al plus the trace metals will also be added as nitrate salts and then precipitated with sodium hydroxide. The freshly precipitated metal hydroxides tend to be gelatinous, amorphous solids with fluid properties that include the presence of yield stress when settled to a low percent insoluble solids bed. Actual sludge while also partially amorphous also has higher amount of oxides based on x-ray analysis. Previous simulant development for Hanford demonstrated that thermal treatment of a precipitated sludge can lead to the conversion of some of the amorphous hydroxides to oxides ${ }^{7}$. Another approach is to replace a portion of the $\mathrm{Fe}$ and $\mathrm{Al}$ with specific oxides to increase the crystalline nature of the sludge and to modify the sludge simulant dissolution properties. Therefore, both thermal treatment and oxide replacement were used in formulating the ECC hazardous sludge simulants. The ferric oxide to be used as a portion of the iron species is the $<5$ micron, $\geq 99 \%$ $\mathrm{Fe}_{2} \mathrm{O}_{3}$ obtained from Sigma Aldrich. The small particle size was chosen to minimize the potential for separation from the precipitated sludge solids. The $\mathrm{Al}$ species added were either $\mathrm{Al}(\mathrm{OH})_{3}$ or $\mathrm{Al}_{2} \mathrm{O}_{3}$.

The ECC Purex hazardous sludge simulant was prepared as described in section 2.1 using a composition that had $38 \%$ of the iron added as ferric nitrate and $68 \%$ of the iron added as the ferric oxide. The aluminum in the Purex simulant was mostly added as $\mathrm{Al}(\mathrm{OH})_{3}(90 \%)$ and $\mathrm{Al}_{2} \mathrm{O}_{3}$ as the remaining $10 \%$. This produced a simulant that settles very quickly which quickly changes a sample from homogenous to heterogeneous. Such a transition prevents the accurate measurement of rheology by rotational methods from being performed. Therefore, rheology measurements were not made. The physical properties of the simulant are listed in Table 3-1.

Table 3-1. Physical Properties of Purex ECC Sludge Simulant

\begin{tabular}{||c|c||}
\hline \multicolumn{1}{|c|}{ Property } & Result \\
\hline \hline Density, g/mL & 1.119 \\
\hline \hline Wt \% Total Solids & 13.55 \\
\hline \hline Wt\% Soluble Solids & 3.05 \\
\hline \hline Wt\% Insoluble Solids & 10.5 \\
\hline $\mathrm{pH}$ & 12.32 \\
\hline
\end{tabular}

The rapid settling of the Purex sludge allows easy concentration to higher insoluble solids loadings just by settling and decanting the supernate. The final measured composition of the sludge simulant is shown in Table 3-2. The ratio to Fe column was included since the ease of concentrating the insoluble portion by settling and decanting will modify the total concentration and the percent of total solids values while the ratio of the insoluble species remains constant. A 
portion of the initial simulant was thermally aged at both 70 and $95{ }^{\circ} \mathrm{C}$ to determine if the dissolution tests could identify differences between the aging conditions.

Table 3-2. Purex Hazardous ECC Sludge Simulant Composition

\begin{tabular}{|c|c|c|c|c|}
\hline Species & Purex Conc. mg/L & Purex wt \% Solids & Ratio to Fe & $\begin{array}{c}\% \text { of } \\
\text { Planned }\end{array}$ \\
\hline $\mathrm{Ag}$ & 52 & 0.03 & 0.001 & 211.5 \\
\hline $\mathrm{Al}$ & 10105 & 6.64 & 0.286 & 77.4 \\
\hline $\mathrm{Ba}$ & 338 & 0.22 & 0.010 & 96.6 \\
\hline $\mathrm{Ca}$ & 3310 & 2.18 & 0.094 & 107.5 \\
\hline $\mathrm{Cd}$ & $<22$ & $<0.010$ & $<0.0006$ & $<216$ \\
\hline $\mathrm{Ce}$ & 340 & 0.22 & 0.010 & 97.3 \\
\hline $\mathrm{Cr}$ & 350 & 0.23 & 0.010 & 100.1 \\
\hline$\overline{\mathrm{Cu}}$ & 173 & 0.11 & 0.005 & 90.5 \\
\hline $\mathrm{Fe}$ & 35383 & 23.25 & 1.000 & 100.0 \\
\hline $\mathrm{K}$ & 189 & 0.12 & 0.005 & 396.9 \\
\hline $\mathrm{La}$ & 205 & 0.13 & 0.006 & 99.1 \\
\hline $\mathrm{Li}$ & 179 & 0.12 & 0.005 & 179.9 \\
\hline $\mathrm{Mg}$ & 155 & 0.10 & 0.004 & 88.8 \\
\hline $\mathrm{Mn}$ & 4568 & 3.00 & 0.129 & 115.0 \\
\hline $\mathrm{Na}$ & 13718 & 9.01 & 0.388 & 130.9 \\
\hline $\mathrm{Ni}$ & 4025 & 2.65 & 0.114 & 99.4 \\
\hline $\mathrm{P}$ & 63 & 0.04 & 0.002 & 86.8 \\
\hline $\mathrm{Pb}$ & 142 & 0.09 & 0.004 & 99.2 \\
\hline $\mathrm{S}$ & 469 & 0.31 & 0.013 & 115.9 \\
\hline $\mathrm{Si}$ & 1307 & 0.86 & 0.037 & 117.5 \\
\hline $\mathrm{Sr}$ & 118 & 0.08 & 0.003 & 996.2 \\
\hline $\mathrm{Zn}$ & 412 & 0.27 & 0.012 & 108.0 \\
\hline $\mathrm{Zr}$ & 612 & 0.40 & 0.017 & 87.5 \\
\hline $\mathrm{Hg}$ & 1757 & 1.16 & 0.050 & 109.5 \\
\hline $\mathrm{F}^{-}$ & $<112$ & $<0.08$ & NA & NA \\
\hline $\mathrm{Cl}^{-}$ & 1673 & 1.10 & NA & NA \\
\hline $\mathrm{NO}_{2}^{-}$ & 10183 & 6.69 & NA & NA \\
\hline $\mathrm{NO}_{3}{ }^{-}$ & 2965 & 1.95 & NA & NA \\
\hline
\end{tabular}

The ECC HM hazardous sludge simulant was prepared as described in section 2.2 using a composition that had $100 \%$ of the iron added as the ferric oxide. The aluminum was added mostly as the aluminum oxide (90\%) to represent the aluminum that may be difficult to leach form HM sludges. The remainder was added as $\mathrm{Al}(\mathrm{OH})_{3}$. The addition of aluminum was made after the thermal aging treatment was completed to prevent caustic dissolution of the insoluble aluminum. Aging was performed only at $95{ }^{\circ} \mathrm{C}$. As in the Purex simulant, the use of the oxides 
produced a sludge which rapidly settles, therefore, the rheology of the simulant was not measured. The physical properties of the final HM simulant are listed in Table 3-3.

Table 3-3. Physical Properties of HM ECC Sludge Simulant

\begin{tabular}{||c||c||}
\hline \multicolumn{1}{|c||}{ Property } & Result \\
\hline \hline Density, g/mL & 1.148 \\
\hline \hline Wt \% Total Solids & 17.2 \\
\hline \hline Wt\% Soluble Solids & 2.00 \\
\hline \hline Wt\% Insoluble Solids & 15.2 \\
\hline \hline $\mathrm{pH}$ & 12.54 \\
\hline
\end{tabular}

The HM simulant was initially formulated to not require any wash steps to allow quicker production of the simulant. When the initial batches of simulant were completed, SRR requested that a washing step be added to minimize the amount of soluble base present in the simulant. As this initial HM product was planned for use in corrosion testing, the washing step was applied after all of the chemical additions had been made. Therefore, a reanalysis of the final simulant composition was made and the results are shown for the initial and final product in Table 3-4. The additional wash consisted of a decant of measured amount of the clear supernate (64\% of the total batch) followed by an addition of distilled water of equal volume. The simulant was mixed and allowed to settle. The supernate was again decanted and the volume of decanted supernate determined. A final addition of distilled water was made based upon the volume of the final decant liquid. This wash and two decants removed a substantial amount of soluble solids which is illustrated by the drop in sodium and in the anions and also be in shift the composition of the total solids shown in Table 3-4. The HM simulant recipe describes the steps involved in the wash in Appendix B. Note that in the final version of the recipe, the addition of mercury is made after the additional washing is complete to prevent losses of soluble mercury and to minimize the generation of waste water containing mercury.

Table 3-4. HM Hazardous ECC Sludge Simulant Composition

\begin{tabular}{||c||c||c|c|c|c|c||}
\hline Species & $\begin{array}{c}\text { Initial } \\
\text { Conc. mg/L }\end{array}$ & $\begin{array}{c}\text { Initial wt \% } \\
\text { Solids }\end{array}$ & $\begin{array}{c}\text { Final Conc. } \\
\text { mg/L }\end{array}$ & $\begin{array}{c}\text { Final wt \% } \\
\text { Solids }\end{array}$ & $\begin{array}{c}\text { Final } \\
\text { Ratio to } \\
\text { Fe }\end{array}$ & $\begin{array}{c}\text { \% of } \\
\text { Planned }\end{array}$ \\
\hline $\mathrm{Ag}$ & 50 & 0.02 & $<172$ & $<0.100$ & $<0.032$ & $\mathrm{NA}$ \\
\hline $\mathrm{Al}$ & 55303 & 18.10 & 71935 & 36.42 & 11.65 & 118.7 \\
\hline $\mathrm{Ba}$ & 476 & 0.16 & 506 & 0.26 & 0.08 & 96.3 \\
\hline $\mathrm{Ca}$ & 1146 & 0.38 & 1318 & 0.77 & 0.24 & 111.2 \\
\hline $\mathrm{Cd}$ & $<31$ & $<0.010$ & $<23$ & $<0.010$ & $<0.003$ & NA \\
\hline \hline $\mathrm{Ce}$ & 122 & 0.04 & 135 & 0.07 & 0.02 & 103.8 \\
\hline \hline $\mathrm{Cr}$ & 483 & 0.16 & 140 & 0.07 & 0.02 & 26.4 \\
\hline \hline $\mathrm{Cu}$ & 64 & 0.02 & 102 & 0.05 & 0.02 & 165.0 \\
\hline \hline $\mathrm{Fe}$ & 5775 & 1.89 & 6176 & 3.13 & 1.00 & 100.0 \\
\hline $\mathrm{Ka}$ & 1801 & 0.59 & 290 & 0.15 & 0.05 & 104.7 \\
\hline $\mathrm{Li}$ & 64 & 0.02 & 67 & 0.03 & 0.01 & 99.0 \\
\hline $\mathrm{Mg}$ & 1203 & 0.39 & 1193 & 0.08 & 0.02 & 101.1 \\
\hline $\mathrm{Mn}$ & 5744 & 1.88 & 6435 & 3.26 & 1.04 & 106.8 \\
\hline \hline $\mathrm{Mo}$ & $<31$ & $<0.010$ & $<23$ & $<0.010$ & $<0.003$ & NA \\
\hline $\mathrm{Na}$ & 56005 & 18.33 & 8532 & 4.32 & 1.38 & 12.8 \\
\hline
\end{tabular}




\begin{tabular}{|c||c||c|c|c||c|c||}
\hline Species & $\begin{array}{c}\text { Initial } \\
\text { Conc. mg/L }\end{array}$ & $\begin{array}{c}\text { Initial wt \% } \\
\text { Solids }\end{array}$ & $\begin{array}{c}\text { Final Conc. } \\
\text { mg/L }\end{array}$ & $\begin{array}{c}\text { Final wt \%o } \\
\text { Solids }\end{array}$ & $\begin{array}{c}\text { Final } \\
\text { Ratio to } \\
\text { Fe }\end{array}$ & $\begin{array}{c}\text { \% of } \\
\text { Planned }\end{array}$ \\
\hline \hline $\mathrm{Nd}$ & 44 & 0.01 & 47 & 0.02 & 0.01 & 143.9 \\
\hline $\mathrm{Ni}$ & 657 & 0.22 & 626 & 0.32 & 0.10 & 84.4 \\
\hline $\mathrm{P}$ & 30 & 0.01 & 25 & 0.01 & 0.004 & 63.8 \\
\hline $\mathrm{Pb}$ & 187 & 0.06 & $<172$ & $<0.100$ & $<0) 32$. & NA \\
\hline $\mathrm{S}$ & 607 & 0.20 & 79 & 0.04 & 0.01 & 11.6 \\
\hline $\mathrm{Si}$ & 363 & 0.12 & 302 & 0.15 & 0.05 & 122.3 \\
\hline $\mathrm{Sr}$ & $<31$ & $<0.010$ & 35 & 0.02 & 0.01 & 81.8 \\
\hline $\mathrm{Ti}$ & $<31$ & $<0.010$ & $<23$ & $<0.010$ & $<0.003$ & NA \\
\hline $\mathrm{Zn}$ & 72 & 0.02 & 79 & 0.04 & 0.01 & 91.3 \\
\hline $\mathrm{Zr}$ & 236 & 0.08 & 253 & 0.13 & 0.04 & 93.1 \\
\hline $\mathrm{Hg}$ & 2455 & 0.80 & 3221 & 1.63 & 0.52 & 133.8 \\
\hline $\mathrm{F}-$ & $<124$ & $<0.04$ & $<100$ & $<0.06$ & NA & NA \\
\hline $\mathrm{Cl}^{-}$ & 405 & 0.13 & $<100$ & $<0.06$ & NA & NA \\
\hline $\mathrm{NO}_{2}^{-}$ & 6643 & 2.17 & 695 & 0.40 & NA & NA \\
\hline $\mathrm{NO}_{3}^{-}$ & 35069 & 11.48 & 3730 & 2.17 & NA & NA \\
\hline \hline
\end{tabular}

The ECC Blend hazardous sludge simulant was prepared in exactly the same manner as the of the HM simulant including the late addition of a washing stage. Due to a batching error additional ferric oxide was added to the simulant used in dissolution testing and for corrosion tests. However, the final composition is still valid as representing a blend of both Purex and HM sludges. The iron in the produced Blend simulant, whose composition is given in Table 3-6, was the only addition that did not match the basis given in section 2.3. Therefore, the iron was added as $81 \%$ oxide and 19 percent precipitated. The physical properties of the Blend simulant produced are shown in Table 3-5.

Table 3-5. Physical Properties of Blend ECC Sludge Simulant

\begin{tabular}{||c||c||}
\hline \multicolumn{1}{|c|}{ Property } & Result \\
\hline \hline Density, g/mL & 1.215 \\
\hline \hline Wt \% Total Solids & 23.0 \\
\hline Wt\% Soluble Solids & 3.3 \\
\hline Wt\% Insoluble Solids & 19.7 \\
\hline \hline $\mathrm{pH}$ & 13.07 \\
\hline
\end{tabular}

The recipe in Appendix $\mathrm{C}$ is the final version for the Blend simulant that will match the original compositional target for the blend.

Table 3-6. Blend Hazardous ECC Sludge Simulant Composition

\begin{tabular}{|c||c|c|c||c|c|c||}
\hline Species & $\begin{array}{c}\text { Initial } \\
\text { Conc. mg/L }\end{array}$ & $\begin{array}{c}\text { Initial wt \% } \\
\text { Solids }\end{array}$ & $\begin{array}{c}\text { Final Conc. } \\
\text { mg/L }\end{array}$ & $\begin{array}{c}\text { Final wt \% } \\
\text { Solids }\end{array}$ & $\begin{array}{c}\text { Final } \\
\text { Ratio to } \\
\text { Fe }\end{array}$ & $\begin{array}{c}\text { \% of } \\
\text { Planned }\end{array}$ \\
\hline $\mathrm{Ag}$ & $<40$ & $<0.01$ & $<182$ & $<0.1$ & $<0.004$ & $\mathrm{NA}$ \\
\hline $\mathrm{Al}$ & 40081 & 9.56 & 47331 & 16.95 & 0.71 & 110.5 \\
\hline $\mathrm{Ba}$ & 412 & 0.10 & 374 & 0.13 & 0.01 & 87.5 \\
\hline $\mathrm{Ca}$ & 3773 & 0.90 & 2569 & 1.41 & 0.06 & 104.2 \\
\hline $\mathrm{Cd}$ & $<40$ & $<0.010$ & $<24$ & $<0.01$ & $<0.0004$ & $\mathrm{NA}$ \\
\hline
\end{tabular}




\begin{tabular}{|c||c||c|c||c|c|c||}
\hline Species & $\begin{array}{c}\text { Initial } \\
\text { Conc. mg/L }\end{array}$ & $\begin{array}{c}\text { Initial wt \% } \\
\text { Solids }\end{array}$ & $\begin{array}{c}\text { Final Conc. } \\
\text { mg/L }\end{array}$ & $\begin{array}{c}\text { Final wt \% } \\
\text { Solids }\end{array}$ & $\begin{array}{c}\text { Final } \\
\text { Ratio to } \\
\text { Fe }\end{array}$ & $\begin{array}{c}\text { \% of } \\
\text { Planned }\end{array}$ \\
\hline $\mathrm{Ce}$ & 116 & 0.03 & 120 & 0.04 & 0.00 & 110.5 \\
\hline $\mathrm{Cr}$ & 438 & 0.10 & 376 & 0.13 & 0.01 & 87.2 \\
\hline $\mathrm{Cu}$ & 245 & 0.06 & 281 & 0.10 & 0.00 & 124.9 \\
\hline $\mathrm{Fe}$ & 66452 & 15.85 & 66353 & 23.76 & 1.00 & 100.0 \\
\hline $\mathrm{K}$ & 1914 & 0.46 & 433 & 0.15 & 0.01 & 185.9 \\
\hline $\mathrm{La}$ & 61 & 0.01 & 55 & 0.02 & 0.00 & 97.0 \\
\hline \hline $\mathrm{Li}$ & $<400$ & $<0.100$ & 122 & 0.04 & 0.00 & 98.8 \\
\hline $\mathrm{Mg}$ & 749 & 0.18 & 642 & 0.23 & 0.01 & 88.3 \\
\hline $\mathrm{Mn}$ & 5622 & 1.34 & 5667 & 2.03 & 0.09 & 115.7 \\
\hline $\mathrm{Mo}$ & $<40$ & $<0.010$ & $<24$ & $<0.01$ & $<0.0004$ & NA \\
\hline $\mathrm{Na}$ & 60813 & 14.51 & 13543 & 4.85 & 0.20 & 16.7 \\
\hline $\mathrm{Nd}$ & 45 & 0.01 & 43 & 0.02 & 0.00 & 158.4 \\
\hline $\mathrm{Ni}$ & 4635 & 1.11 & 3493 & 1.25 & 0.05 & 76.9 \\
\hline \hline $\mathrm{P}$ & 217 & 0.05 & 140 & 0.05 & 0.002 & 60.1 \\
\hline $\mathrm{Pb}$ & 182 & 0.04 & $<182$ & $<0.1$ & $<0.004$ & NA \\
\hline $\mathrm{S}$ & 944 & 0.23 & 224 & 0.08 & 0.00 & 25.4 \\
\hline $\mathrm{Si}$ & 1539 & 0.37 & 1408 & 0.50 & 0.02 & 60.6 \\
\hline $\mathrm{Sr}$ & 239 & 0.06 & 271 & 0.10 & 0.00 & 106.2 \\
\hline $\mathrm{Ti}$ & $<40$ & $<0.010$ & $<24$ & $<0.01$ & $<0.0004$ & NA \\
\hline \hline $\mathrm{Zn}$ & 463 & 0.11 & 437 & 0.16 & 0.01 & 100.6 \\
\hline $\mathrm{Zr}$ & 803 & 0.19 & 634 & 0.23 & 0.01 & 75.2 \\
\hline $\mathrm{Hg}$ & 2246 & 0.53 & 2368 & 0.85 & 0.04 & 119.1 \\
\hline $\mathrm{F}-$ & $<130$ & $<0.04$ & $<121$ & $<0.04$ & NA & NA \\
\hline $\mathrm{Cl}-$ & 4121 & 0.98 & 791 & 0.28 & NA & NA \\
\hline \hline $\mathrm{NO}{ }_{2}^{-}$ & 8262 & 1.97 & 1603 & 0.57 & NA & NA \\
\hline $\mathrm{NO}{ }_{3}^{-}$ & 82034 & 19.57 & 15059 & 5.39 & NA & NA \\
\hline & & & & & & \\
\hline
\end{tabular}

\subsection{Acid Dissolution Results}

Acid dissolution test were performed with four different sludge simulants. The first two simulants were Purex simulants prepared using either a $70{ }^{\circ} \mathrm{C}$ thermal aging step or a $95{ }^{\circ} \mathrm{C}$ thermal aging step. The final two simulants were the HM and Blend simulants which were both thermally aged at $95{ }^{\circ} \mathrm{C}$. The acids tested were 0.11 molar oxalic, nitric and sulfuric acids and the acids were added at a 100:1 mass to mass of sludge solids ratio. For comparison to the later described titration ratio measurements this is probably in the range of 100 to 200 on a volume to volume basis. Additionally samples of the ferric oxide $(<5$ micron $\geq 99 \%$, Sigma Aldrich) and aluminum oxide were also tested for the degree of dissolution. The tests were run at $25{ }^{\circ} \mathrm{C}$ for seven days under continuous agitation as described in section 2.5. A portion of the supernate was then removed and analyzed for the soluble metal content and compared to the metal content placed in the dissolution vials. The $\mathrm{pH}$ of the dissolution supernates was measured after the testing was complete and the $\mathrm{pH}$ of the oxalic acid test mixtures averaged 1.58 compared to an initial $\mathrm{pH}$ of 1.64. The nitric acid test mixtures averaged a $\mathrm{pH}$ of 1.44 compared to an initial $\mathrm{pH}$ of 1.41 and the sulfuric acid test mixtures averaged a $\mathrm{pH}$ of 1.44 compared to an initial $\mathrm{pH}$ of 1.43. 
Results from the simulant testing are compared below to actual waste testing performed in the shielded cells ${ }^{8}$ and in actual cleaning tests on Tanks $5 \mathrm{~F}^{9}$ and $6 \mathrm{~F}^{10}$.

Dissolution results for iron for the new simulants shown in Table 3-7 are considerably better than for the previous simulant which showed nearly complete dissolution for iron with oxalic acid at dissolution temperatures as low as $25^{\circ} \mathrm{C} .{ }^{11}$ The amount of ferric oxide to use in the Purex and Blend simulants was based on earlier estimates of actual waste dissolution results and seem to reflect on the values measured in this test. The extremely low dissolution result for the HM simulant may be a consequence of the small amount of iron relative to the amount of other solids present leading to mass transfer issues.

Table 3-7. Acid Dissolution Results for Iron

\begin{tabular}{|c|c|c|c||c|c|c|c|c||}
\hline Iron & $\begin{array}{c}\text { Purex } \\
\mathbf{7 0}^{\circ} \mathbf{C}\end{array}$ & $\begin{array}{c}\text { Purex } \\
\mathbf{9 5}{ }^{\circ} \mathbf{C}\end{array}$ & $\mathbf{H M}$ & Blended & $\mathbf{F e}_{2} \mathbf{O}_{3}$ & $\begin{array}{c}\text { SRNL } \\
\text { Tank } \\
\mathbf{5 F}\end{array}$ & Tank 5F & $\begin{array}{c}\text { Tank } \\
\mathbf{6 F}\end{array}$ \\
\hline $\begin{array}{c}\text { Oxalic } \\
\text { Acid, \% } \\
\text { dissolved }\end{array}$ & $50.4 \pm 5.3$ & $\begin{array}{c}47.7 \pm \\
3.1\end{array}$ & $\begin{array}{c}10.4 \pm \\
0.3\end{array}$ & $\begin{array}{c}72.8 \pm \\
1.5\end{array}$ & 40.1 & 62 & 21 & 69 \\
\hline $\begin{array}{c}\text { Nitric } \\
\text { Acid, \% } \\
\text { dissolved }\end{array}$ & $25.0 \pm 0.1$ & $6.8 \pm 0.7$ & $<0.04$ & $\begin{array}{c}21.9 \pm \\
0.2\end{array}$ & 0.17 & NA & NA & NA \\
\hline $\begin{array}{c}\text { Sulfuric } \\
\text { Acid, \% } \\
\text { dissolved }\end{array}$ & $28.3 \pm 0.8$ & $\begin{array}{c}16.5 \pm \\
0.1\end{array}$ & $\begin{array}{c}0.94 \pm \\
0.04\end{array}$ & $\begin{array}{c}22.7 \pm \\
0.3\end{array}$ & 3.8 & NA & NA & NA \\
\hline $\begin{array}{c}\text { Dissolution } \\
\text { Temp, }{ }^{\circ} \mathrm{C}\end{array}$ & 25 & 25 & 25 & 25 & 25 & 50 & 40 & 40 \\
\hline $\begin{array}{c}\% \text { Fe as } \\
\text { Fe } \mathrm{O}_{3}\end{array}$ & 68 & 68 & 100 & 81 & NA & NA & NA & NA \\
\hline $\begin{array}{c}\text { Precipitated } \\
\text { Fe, \% }\end{array}$ & 32 & 32 & 0 & 19 & NA & NA & NA & NA \\
\hline $\begin{array}{c}\text { Heat Treat } \\
\text { Temp, }{ }^{\circ} \mathrm{C}\end{array}$ & 70 & 95 & 95 & 95 & NA & NA & NA & NA \\
\hline \hline $\begin{array}{c}\text { Washed } \\
\text { before Heat }\end{array}$ & Yes & Yes & No & No & NA & NA & NA & NA \\
\hline
\end{tabular}

The aluminum dissolution results shown in Table 3-8 demonstrate that the three simulants as formulated and produced are very resistant to dilute acid dissolution, whether by oxalic acid or by either nitric or sulfuric acid. While these simulants may be excessively conservative toward aluminum they insure that some insoluble particles will remain for evaluating impacts on the ECC process.

Table 3-8. Acid Dissolution Results for Aluminum

\begin{tabular}{|c|c|c|c|c|c|c|c|c|}
\hline Aluminum & $\begin{array}{l}\text { Purex } \\
70^{\circ} \mathrm{C}\end{array}$ & $\begin{array}{l}\text { Purex } \\
95^{\circ} \mathrm{C}\end{array}$ & HM & Blended & $\mathrm{Al}_{2} \mathbf{O}_{3}$ & $\begin{array}{c}\text { SRNL } \\
\text { Tank } \\
5 F\end{array}$ & Tank 5F & $\begin{array}{c}\text { Tank } \\
\text { 6F }\end{array}$ \\
\hline $\begin{array}{c}\text { Oxalic } \\
\text { Acid, \% } \\
\text { dissolved }\end{array}$ & $4.9 \pm 0.3$ & $3.6 \pm 0.4$ & $\begin{array}{c}4.04 \pm \\
0.04\end{array}$ & $\begin{array}{c}13.1 \pm \\
0.2\end{array}$ & 0.03 & 84 & 81 & 85 \\
\hline $\begin{array}{c}\text { Nitric } \\
\text { Acid, \% } \\
\text { dissolved }\end{array}$ & $2.4 \pm 0.04$ & $\begin{array}{l}1.1 \pm \\
0.03\end{array}$ & $\begin{array}{c}3.9 \pm \\
0.05\end{array}$ & $\begin{array}{c}13.4 \pm \\
0.5\end{array}$ & 0.03 & NA & NA & NA \\
\hline
\end{tabular}




\begin{tabular}{|c|c|c|c|c|c|c|c|c|}
\hline Aluminum & $\begin{array}{l}\text { Purex } \\
70^{\circ} \mathrm{C}\end{array}$ & $\begin{array}{l}\text { Purex } \\
95^{\circ} \mathrm{C}\end{array}$ & HM & Blended & $\mathbf{A l}_{2} \mathbf{O}_{3}$ & $\begin{array}{c}\text { SRNL } \\
\text { Tank } \\
\text { 5F }\end{array}$ & Tank 5F & $\begin{array}{c}\text { Tank } \\
\text { 6F }\end{array}$ \\
\hline $\begin{array}{c}\text { Sulfuric } \\
\text { Acid, \% } \\
\text { dissolved }\end{array}$ & $5.0 \pm 0.2$ & $\begin{array}{c}4.32 \pm \\
0.06\end{array}$ & $\begin{array}{c}4.07 \pm \\
0.07\end{array}$ & $\begin{array}{c}13.6 \pm \\
0.2\end{array}$ & 0.04 & NA & NA & NA \\
\hline $\begin{array}{c}\text { Dissolution } \\
\text { Temp, }{ }^{\circ} \mathrm{C}\end{array}$ & 25 & 25 & 25 & 25 & 25 & 50 & 40 & 40 \\
\hline $\begin{array}{c}\% \mathrm{Al}_{2} \mathrm{O}_{3} \text { in } \\
\text { recipe }\end{array}$ & 10 & 10 & 100 & 90 & NA & NA & NA & NA \\
\hline $\begin{array}{c}\% \mathrm{Al}(\mathrm{OH})_{3} \\
\text { in recipe }\end{array}$ & 90 & 90 & 0 & 10 & NA & NA & NA & NA \\
\hline $\begin{array}{l}\text { Heat Treat } \\
\text { Temp, }{ }^{\circ} \mathrm{C} \\
\end{array}$ & 70 & 95 & 95 & 95 & NA & NA & NA & NA \\
\hline $\begin{array}{c}\text { Washed } \\
\text { before Heat }\end{array}$ & Yes & Yes & No & No & NA & NA & NA & NA \\
\hline
\end{tabular}

The manganese results for the Purex simulant are in line with previous simulant results and with the actual waste tests using Purex sludges (Tanks 5F and 6F) as shown in Table 3-9. Since both simulants produce the hydrated $\mathrm{MnO}_{2}$ by the same generation step, agreement was expected. However, the higher degree of dissolution observed in the HM and Blend simulants may be indicating that applying a thermal aging step with higher levels of hydroxide and higher ionic strength could be impacting the acid resistance of the $\mathrm{Mn}$ in the sludge. Both the HM and Blend simulants are not washed before applying the $95{ }^{\circ} \mathrm{C}$ aging step. Future simulant development should consider testing what other species may be affected caustic strength during processes designed to accelerate the aging of a simulated sludge.

Table 3-9. Acid Dissolution Results for Manganese

\begin{tabular}{|c|c|c|c|c|c|c|c|}
\hline Manganese & $\begin{array}{l}\text { Purex } \\
70^{\circ} \mathrm{C}\end{array}$ & $\begin{array}{l}\text { Purex } \\
95^{\circ} \mathrm{C}\end{array}$ & HM & Blended & $\begin{array}{c}\text { SRNL } \\
\text { Tank } \\
\text { 5F }\end{array}$ & Tank 5F & $\begin{array}{c}\text { Tank } \\
\text { 6F }\end{array}$ \\
\hline $\begin{array}{c}\text { Oxalic } \\
\text { Acid, \% } \\
\text { dissolved }\end{array}$ & $46.9 \pm 1.6$ & $\begin{array}{c}31.9 \pm \\
0.6\end{array}$ & $90 \pm 2$ & $86 \pm 33$ & 40 & 40 & 47 \\
\hline $\begin{array}{c}\text { Nitric } \\
\text { Acid, \% } \\
\text { dissolved }\end{array}$ & $85 \pm 1$ & $\begin{array}{c}42.8 \pm \\
0.8\end{array}$ & $\begin{array}{c}29.7 \pm \\
0.6\end{array}$ & $\begin{array}{c}58.8 \pm \\
2.2\end{array}$ & NA & NA & NA \\
\hline $\begin{array}{c}\text { Sulfuric } \\
\text { Acid, \% } \\
\text { dissolved }\end{array}$ & $88 \pm 3$ & $\begin{array}{c}48.1 \pm \\
0.6\end{array}$ & $\begin{array}{c}30.9 \pm \\
0.4\end{array}$ & $60 \pm 8$ & NA & NA & NA \\
\hline $\begin{array}{c}\text { Dissolution } \\
\text { Temp, }{ }^{\circ} \mathrm{C}\end{array}$ & 25 & 25 & 25 & 25 & 50 & 40 & 40 \\
\hline $\begin{array}{l}\text { Heat Treat } \\
\text { Temp, }{ }^{\circ} \mathrm{C}\end{array}$ & 70 & 95 & 95 & 95 & NA & NA & NA \\
\hline $\begin{array}{c}\text { Washed } \\
\text { before Heat }\end{array}$ & Yes & Yes & No & No & NA & NA & NA \\
\hline
\end{tabular}

The nickel dissolution results are shown in Table 3-10 and are in agreement with actual waste tests except for the HM simulant. The primary difference between the HM simulant and the other simulants is the very low level of nickel present in the HM simulant. Since the low dissolution is assumed to be due to the formation of an insoluble nickel oxalate, the result for the HM simulant 
may be related to the solubility limit for nickel. Nickel in the HM simulant is factor of five lower in concentration than in the Blend simulant.

Table 3-10. Acid Dissolution Results for Nickel

\begin{tabular}{|c|c|c|c|c|c|c|c|}
\hline Nickel & $\begin{array}{l}\text { Purex } \\
70^{\circ} \mathrm{C}\end{array}$ & $\begin{array}{l}\text { Purex } \\
95^{\circ} \mathrm{C}\end{array}$ & HM & Blended & $\begin{array}{c}\text { SRNL } \\
\text { Tank } \\
\text { 5F }\end{array}$ & Tank 5F & $\begin{array}{c}\text { Tank } \\
\text { 6F }\end{array}$ \\
\hline $\begin{array}{c}\text { Oxalic } \\
\text { Acid, \% } \\
\text { dissolved }\end{array}$ & $2.7 \pm 0.2$ & $1.8 \pm 0.9$ & $84 \pm 8$ & $\begin{array}{c}10.4 \pm \\
1.3\end{array}$ & 0.1 & 0.6 & 1.7 \\
\hline $\begin{array}{c}\text { Nitric } \\
\text { Acid, \% } \\
\text { dissolved }\end{array}$ & $93 \pm 1$ & $22 \pm 3$ & $\begin{array}{c}95.4 \pm \\
1.5\end{array}$ & $138 \pm 4$ & NA & NA & NA \\
\hline $\begin{array}{c}\text { Sulfuric } \\
\text { Acid, \% } \\
\text { dissolved }\end{array}$ & $101 \pm 3$ & $\begin{array}{c}51.5 \pm \\
0.8\end{array}$ & $\begin{array}{c}97.2 \pm \\
0.9\end{array}$ & $132 \pm 2$ & NA & NA & NA \\
\hline $\begin{array}{c}\text { Dissolution } \\
\text { Temp, }{ }^{\circ} \mathrm{C}\end{array}$ & 25 & 25 & 25 & 25 & 50 & 40 & 40 \\
\hline $\begin{array}{l}\text { Heat Treat } \\
\text { Temp, }{ }^{\circ} \mathrm{C}\end{array}$ & 70 & 95 & 95 & 95 & NA & NA & NA \\
\hline $\begin{array}{c}\text { Washed } \\
\text { before Heat }\end{array}$ & Yes & Yes & No & No & NA & NA & NA \\
\hline
\end{tabular}

Calcium and lead dissolution results are shown in Table 3-11 and Table 3-12. The primary difference between the Purex simulant and the HM and Blend simulants is that all of the calcium is added as calcium compounds in the Purex simulant while either all or some of the calcium in the other simulants is added as calcium nitrate and precipitated with hydroxide. This difference may explain the solubility differences between these tests.

Table 3-11. Acid Dissolution Results for Calcium

\begin{tabular}{|c|c|c|c|c|c|c|}
\hline Calcium & $\begin{array}{l}\text { Purex } \\
70^{\circ} \mathrm{C}\end{array}$ & $\begin{array}{l}\text { Purex } \\
95^{\circ} \mathrm{C}\end{array}$ & HM & Blended & Tank 5F & $\begin{array}{c}\text { Tank } \\
\text { 6F }\end{array}$ \\
\hline $\begin{array}{c}\text { Oxalic } \\
\text { Acid, \% } \\
\text { dissolved } \\
\end{array}$ & $26.8 \pm 1.0$ & $\begin{array}{c}25.6 \pm \\
0.5\end{array}$ & $\begin{array}{c}64.7 \pm \\
3.7\end{array}$ & $\begin{array}{c}66.7 \pm \\
2.2\end{array}$ & 92 & 91 \\
\hline $\begin{array}{c}\text { Nitric } \\
\text { Acid, \% } \\
\text { dissolved } \\
\end{array}$ & $88 \pm 6$ & $86 \pm 17$ & $\begin{array}{c}111 \pm \\
2\end{array}$ & $139 \pm 14$ & NA & NA \\
\hline $\begin{array}{c}\text { Sulfuric } \\
\text { Acid, \% } \\
\text { dissolved } \\
\end{array}$ & $87 \pm 6$ & $\begin{array}{c}85.2 \pm \\
0.9\end{array}$ & $\begin{array}{c}115 \pm \\
2\end{array}$ & $131 \pm 15$ & NA & NA \\
\hline $\begin{array}{c}\text { Dissolution } \\
\text { Temp, }{ }^{\circ} \mathrm{C}\end{array}$ & 25 & 25 & 25 & 25 & 40 & 40 \\
\hline $\begin{array}{l}\text { Heat Treat } \\
\text { Temp, }{ }^{\circ} \mathrm{C} \\
\end{array}$ & 70 & 95 & 95 & 95 & NA & NA \\
\hline $\begin{array}{c}\text { Washed } \\
\text { before Heat }\end{array}$ & Yes & Yes & No & No & NA & NA \\
\hline
\end{tabular}


Table 3-12. Acid Dissolution Results for Lead

\begin{tabular}{||c|c||c|c||c||}
\hline Lead & $\begin{array}{c}\text { Purex } \\
\mathbf{7 0}^{\circ} \mathbf{C}\end{array}$ & $\begin{array}{c}\text { Purex } \\
\mathbf{9 5}{ }^{\circ} \mathbf{C}\end{array}$ & HM & Blended \\
\hline $\begin{array}{c}\text { Oxalic } \\
\text { Acid, \% } \\
\text { dissolved }\end{array}$ & $26 \pm 8$ & $26 \pm 4$ & $31 \pm 4$ & $38 \pm 5$ \\
\hline $\begin{array}{c}\text { Nitric } \\
\text { Acid, \% } \\
\text { dissolved }\end{array}$ & $101 \pm 3$ & $57 \pm 5$ & $\begin{array}{c}33.6 \pm \\
1.8\end{array}$ & $33 \pm 39$ \\
\hline $\begin{array}{c}\text { Sulfuric } \\
\text { Acid, \% } \\
\text { dissolved }\end{array}$ & $13.2 \pm 2.6$ & $7.3 \pm 0.7$ & $\begin{array}{c}6.7 \pm \\
0.5\end{array}$ & $24 \pm 11$ \\
\hline $\begin{array}{c}\text { Heat Treat } \\
\text { Temp, }{ }^{\circ} \mathrm{C}\end{array}$ & 70 & 95 & 95 & 95 \\
\hline $\begin{array}{c}\text { Washed } \\
\text { before Heat }\end{array}$ & Yes & Yes & No & No \\
\hline
\end{tabular}

\subsection{Oxalic Acid Titrations}

The ECC process involves adding sufficient $1 \mathrm{wt} \%$ oxalic acid to the residual sludge to obtain a $\mathrm{pH}$ less than 2. As part of the simulant development process, SRR requested that the amount of oxalic acid required to perform the $\mathrm{pH}$ adjustment be determined. The current plans for processing the sludge simulant include allowing the simulant to settle and decanting supernate to minimize the amount of acid to reach the $\mathrm{pH}$ adjustment target value. For the titration tests to be performed, enough supernate must remain with the settled solids to allow easy transfer from the settling vessel to the titration vessel. Therefore, the process used for preparing the titration sample was to weigh out a known mass of simulant into four $50 \mathrm{~mL}$ centrifuge tubes and concentrate the solids at a low centrifuge speed $(500 \mathrm{rpm})$ for five minutes and remove about half the total volume as clear supernate. The amount of concentrated sludge solids remaining is weighed and transferred to a titration beaker for the titration. The nominal volume of concentrated simulant titrated was about $100 \mathrm{~mL}$ for the Purex and HM simulants and about 114 $\mathrm{mL}$ for the Blend simulant.

The titration curves for each of the three simulants are shown in Figure 3-1, Figure 3-2 and Figure 3-3. A typical acid-base titration curve is a smooth curve with one or more breaks in the curve since acid-base reactions for soluble species are usually fast. The potential breaks in the titration curve would be due to hydroxide and carbonate between $\mathrm{pH} 10$ and 6 and then nitrite below 6. Gas generation presumably due to $\mathrm{CO}_{2}$ generation was observed in all three titrations. For sludge slurries, however, portions of the acid-reactive species are insoluble and the kinetics of dissolution/reaction can be slow and will impact the resulting measurements of $\mathrm{pH}$. As a result, any break in the process due to having to stop for an evening or other reason (fouled $\mathrm{pH}$ probe, etc.) will allow the $\mathrm{pH}$ to drift higher until the entire insoluble base is reacted. These periods produce the vertical jumps which exist in the three $\mathrm{pH}$ curves displayed below. The Blend simulant titration shows a number of vertical breaks due to the $\mathrm{pH}$ drifting to higher $\mathrm{pH}$ values when checked the next day. The vertical line on all three figures indicates when the titrated sample had to be split into two separate portions due to the volume at that point exceeding the titration vessel size. The total volume of oxalic acid added to a specific simulant can be determined by summing the volume at the largest volume for each curve minus twice the batch split volume. For example, for the Purex simulant the calculation is Initial Portion volume (950 $\mathrm{mL}$ ) plus First Portion volume $(1100 \mathrm{~mL})$ plus Second Portion volume $(1025 \mathrm{~mL})$ minus 2 times the Initial Portion. Therefore, the Purex titration volume is $1175 \mathrm{~mL}$. 


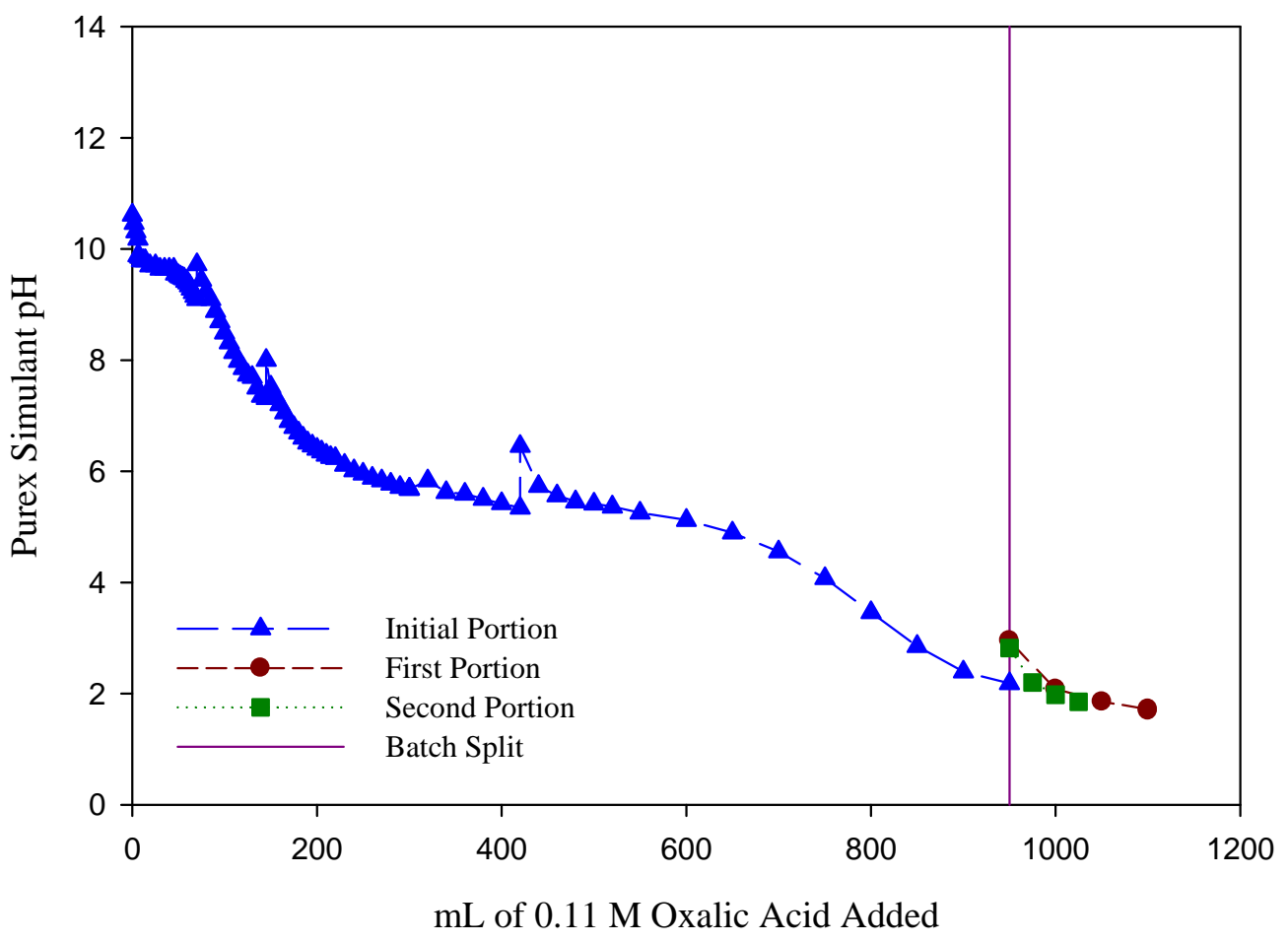

Figure 3-1. Titration of ECC Purex Sludge Simulant

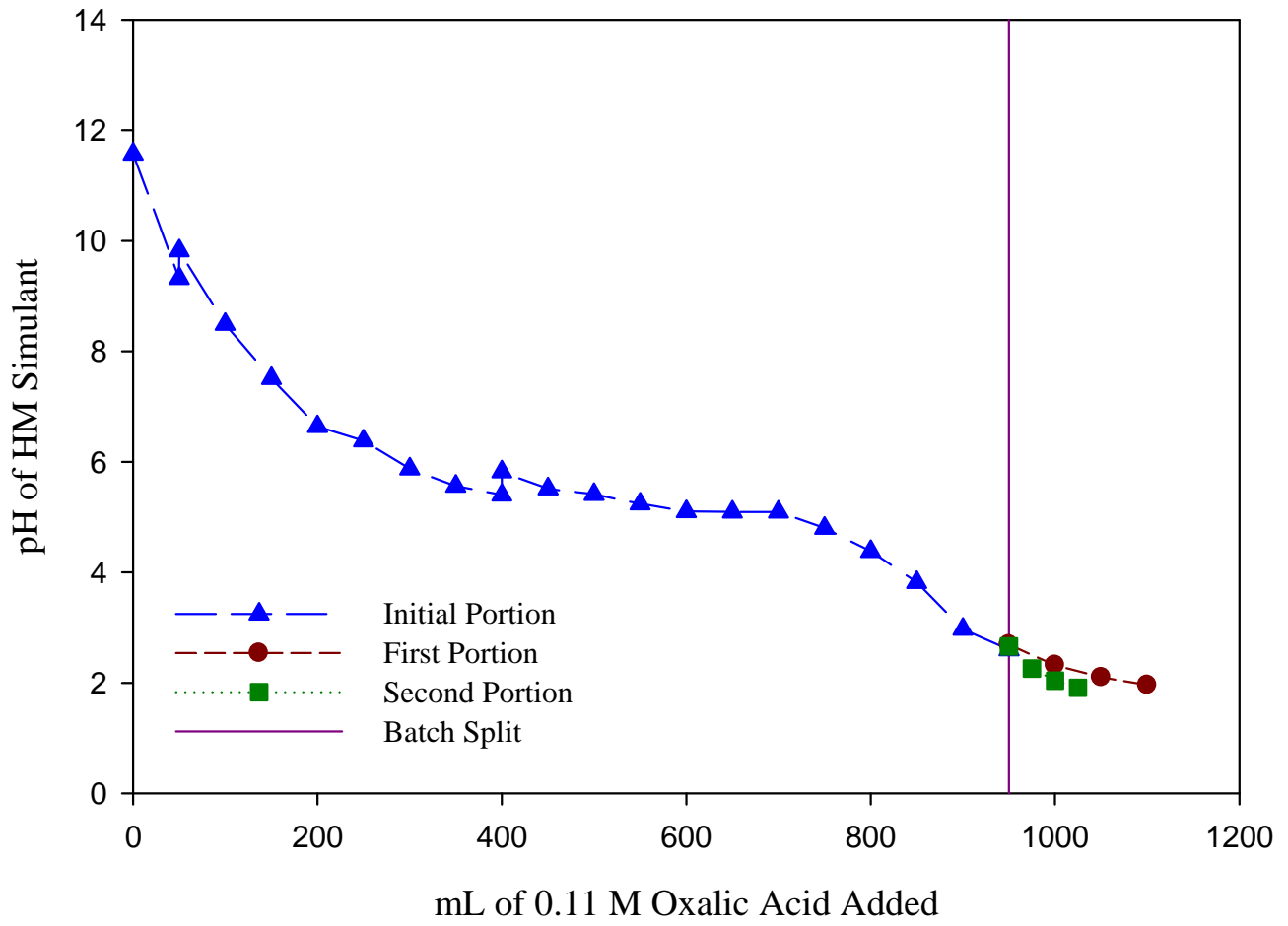

Figure 3-2. Titration of ECC HM Sludge Simulant 


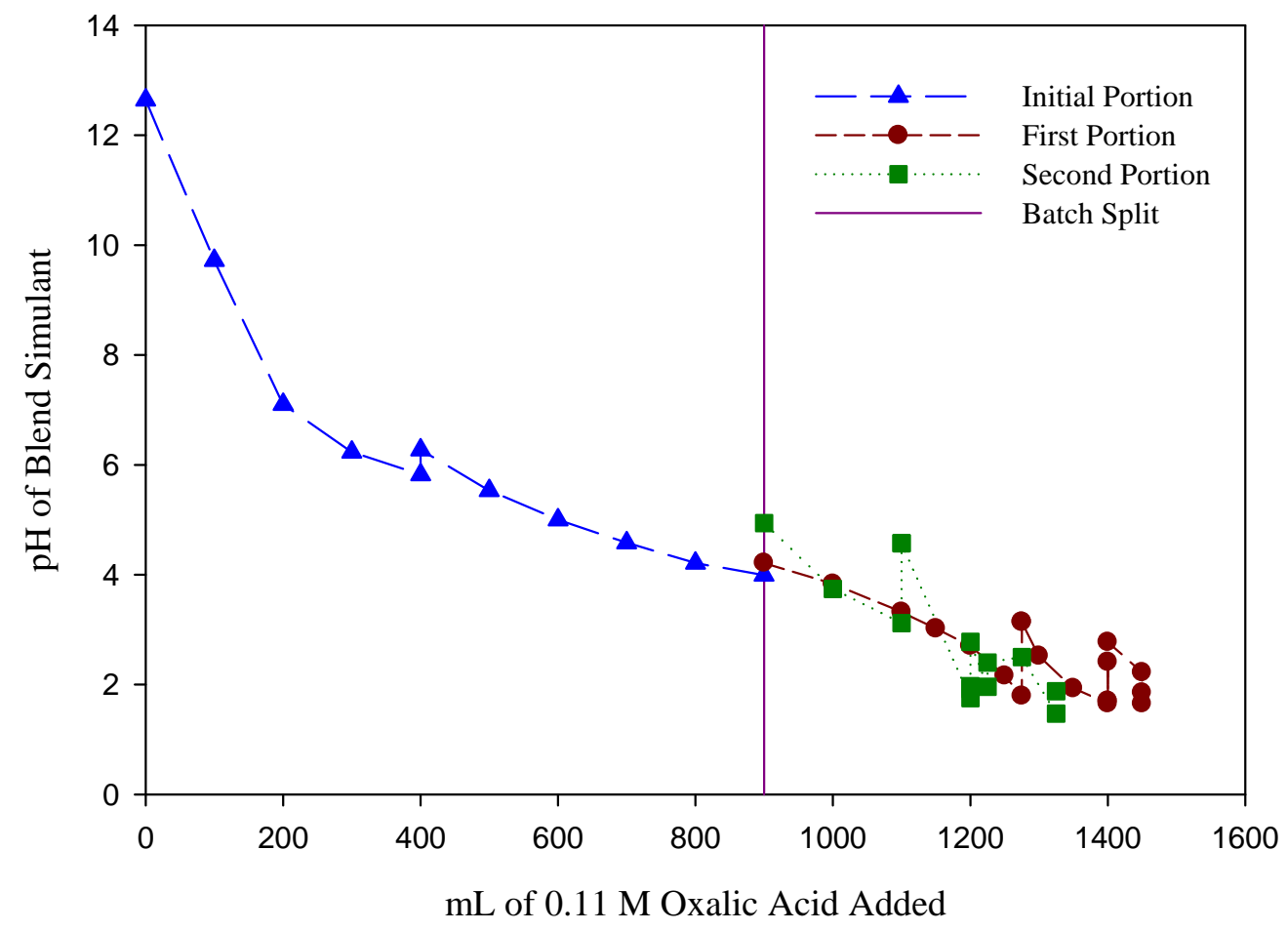

Figure 3-3. Titration of ECC Blend Sludge Simulant

The titration results for all three simulants are summarized in Table 3-13. These results should be considered to be the minimum amount of one weight percent oxalic acid required to achieve a $\mathrm{pH}$ of less than 2 as a function of the degree to which the solids were settled and the amount of residual supernate left with the solids. The Blend simulant, for example, had a higher volume of solids potentially containing more supernate with more acid-reactive capacity which would impact the amount of acid required.

Table 3-13. Summary of Simulant Titration Results

\begin{tabular}{|c||c||c||c||c||}
\hline \hline Simulant & $\begin{array}{c}\text { Simulant Vol., } \\
\text { mL }\end{array}$ & $\begin{array}{c}\text { Conc Sludge } \\
\text { Vol., } \mathbf{~ m L}\end{array}$ & $\begin{array}{c}\text { Titration Volume, } \\
\text { mL }\end{array}$ & $\begin{array}{c}\text { Ratio } \\
\text { Titrant/Sludge }\end{array}$ \\
\hline \hline Purex & 196 & 98 & 1175 & 12.0 \\
\hline \hline HM & 197 & 97 & 1175 & 12.1 \\
\hline \hline Blend & 197 & 114 & 1875 & 16.4 \\
\hline
\end{tabular}

The drift observed in $\mathrm{pH}$ as a function of time is especially apparent in the titration curve for the Blend simulant, Figure 3-3. The titration for that simulant was performed over an 8 day period with all of the data for the initial day covering the initial portion, the first portion out to $1275 \mathrm{~mL}$ and the second portion out to $1100 \mathrm{~mL}$. The remaining data was collected on day two, day three and day eight. To further highlight the issue of stability of the final $\mathrm{pH}$ measurement after additional time, additional measurements were made more than two weeks after completion of the titrations and the data is shown in Table 3-14. 
Table 3-14. Stability of pH for Acid Adjusted Simulants

\begin{tabular}{|c||c|c||c||}
\hline Simulant & $\begin{array}{c}\text { Final } \\
\text { Titration } \\
\mathbf{p H}\end{array}$ & $\begin{array}{c}\text { Later } \\
\mathbf{p H}\end{array}$ & $\begin{array}{c}\text { Days between } \\
\mathbf{p H} \\
\text { measurements }\end{array}$ \\
\hline \hline Purex & 1.78 & 2.34 & 34 \\
\hline \hline HM & 1.85 & 1.89 & 29 \\
\hline \hline Blend & 1.85 & 2.97 & 20 \\
\hline
\end{tabular}

The acid-adjusted HM simulant appears to be at equilibrium while the Purex and Blend simulants continue to drift to higher $\mathrm{pH}$ levels. Both the Purex and Blend simulants added some of the metals as specific solids such as calcium carbonate, calcium phosphate and calcium sulfate whose slow dissolution probably impacts the achievement of an equilibrium $\mathrm{pH}$ while the HM simulant uses metal nitrates and sodium salts and relies totally on precipitation end equilibrium to generate the final solids of the simulant. Storage vessel composition can also impact $\mathrm{pH}$ if the vessel is composed of and acid-reactive solid such as carbon steel. All of the titration products were transferred from the glass beakers to polypropylene bottles so the $\mathrm{pH}$ shifts observed must be due to the solids present within the simulants.

\subsection{Conclusions}

Savannah River Remediation has requested the Savannah River National Laboratory to develop and produce three new sludge simulants that are resistant to oxalic acid dissolution and contain RCRA hazardous metals for use in additional planned Enhanced Chemical Cleaning process tests. The results of the simulant development are:

- The development and production of lab-scale quantities of the Purex, HM and Blend simulants has been completed.

- The hazardous metals in the new simulants are mercury, silver, barium, cadmium, chromium and lead with the mercury present at HM waste levels in all three simulants.

- The resistance of the three simulants to oxalic acid is similar to or more resistant than actual radioactive waste in prior lab and plant tests.

- The minimum amount of one weight percent oxalic acid required to adjust the $\mathrm{pH}$ of the three new simulants was determined to be from 12 to 16.4 times the volume of decanted simulant.

- At the minimum acid quantity, the simulant $\mathrm{pH}$ will tend to drift above $\mathrm{pH} 2$ due to the slow reaction kinetics of the acid reactive sludge solids. Addition of more acid over time will be required to maintain a $\mathrm{pH}$ below 2 .

- Sufficient quantities of each simulant were prepared for use in corrosion testing as requested by SRR.

Any additional improvement in the simulant properties with respect to actual waste using the approach applied to the current simulants will require more detailed information about the specific compounds present in actual radioactive sludge. Such information may provide alternative choices for the mineral phases that could be used in the production of simulants to represent the sludge heels in high level waste tanks to be closed. 


\subsection{References}

1 S. Dennis Jones, "Savannah River Enhanced Chemical Cleaning Sludge Simulant Demonstration” AREVA NP Inc. report \#51-9063140-000, October 9, 2007.

${ }^{2}$ E. T. Ketusky, "Enhanced Chemical Cleaning (ECC) Hazardous Simulant Development \& Treatment Tank Corrosion Testing,” HLE-TTR-2009-116, Rev. 0.

3 H. H. Elder, "Position Paper on Sludge Batch 2 Qualification Strategy and Simulant Composition,” HLW-SDT-2000-00128, Rev. 0.

${ }^{4}$ R. F. Swingle, N. Bibler, T. Fellinger, “Tank 8F Sludge Slurry Analysis Results,” WSRC-RP2000-00962, Rev. 0.

${ }^{5}$ S. H. Reboul, K. E. Zeigler, "Elemental Composition of Tank 12 Sludge Slurry Solids," SRNLL3100-2008-00089.

${ }^{6}$ S. H. Reboul, “Tank 12 Sludge Constituents for Aluminum Dissolution Flowsheet," SRNLL3100-2008-00050.

${ }^{7}$ R. E. Eibling, R. F. Schumacher, E. K. Hansen, "Development of Simulants to Support Mixing Tests for High Level Waste and Low Activity Waste,” WSRC-TR-2003-00220, Rev. 0.

${ }^{8}$ M. S. Hay, K. P. Crapse, S. D. Fink, J. M. Pareizs, "Characterization and Actual Waste Tests with Tank 5F Samples”, WSRC-STI-2007-00192, Rev. 1.

${ }^{9}$ M. R. Poirier, S. D. Fink, “Analysis of Samples from Tank 5F Chemical Cleaning,” SRNL-STI2009-00492, Rev. 0.

${ }^{10}$ M. R. Poirier, S. D. Fink, “Analysis of Samples from Tank 6F Chemical Cleaning,” SRNLSTI-2009-00493, Rev. 0.

${ }^{11}$ D. T. Herman, B. J. Wiersma, F. F. Fondeur, J. C. Wittkop, J. M. Pareizs, K. P. Crapse, M. S. Hay, M. R. Poirier, S. D. Fink, "Investigating Hydrogen Generation and Corrosion in the Treatment Tank and the Potential Formation of a Floating Layer in Neutralization Tank During Waste Tank Heel Chemical Cleaning,” WSRC-STI-2007-00209, Rev. 0. 
SRNL-STI-2010-00170

Revision 0

Appendix A: ECC Purex Hazardous Sludge Simulant Recipe 


\section{ECC Purex Hazardous Sludge Simulant Recipe}

Development of the ECC hazardous Purex simulant used reagent grade chemicals and a specific oxide of known particle size. The specific metal oxide is ferric oxide, $<5$ micron, $>99 \%$ purity, purchased from Sigma-Aldrich. Substitutions for this ferric oxide should not be made without additional studies. However, technical grade chemicals may be sufficient for replacing the reagent grade chemicals when producing larger scale quantities of the simulant. These technical grade chemicals should be at least $97 \%$ pure. Care in choosing the technical grade chemicals are necessary to prevent the trace contaminants in the technical grade from swamping the intended concentration of minor waste species.

Many of the salts used in the simulant include waters of hydration and the specific form to be used is shown in the recipe. Care must be taken in storing and using some of these compounds due to their tendency to readily absorb water. Using a salt, which has obviously absorbed excess water, will lead to missing the target value for that compound. When necessary, a solution of the compound can be used. However, the water additions shown in the recipe will have to be appropriately reduced to account for the water in the solution of the compound.

The recipe is formulated below based on production of a one liter quantity of simulant with properties as stated in the body of the report. Larger volumes can be prepared by scaling the chemicals, liquids and vessels in the recipe as needed

\section{ECC Hazardous Purex Sludge Simulant Preparation}

Goal: Volume of Purex Simulant to be produced

$1,000.0 \mathrm{~mL}$

\section{PART I: Hydrated Manganese Dioxide, $\mathrm{MnO}_{2}$, Preparation}

Add the following to separate vessels: $\left(\mathrm{KMnO}_{4}\right.$ solution will then be fed to the $\mathrm{Mn}\left(\mathrm{NO}_{3}\right)_{2}$ vessel, both at $40^{\circ} \mathrm{C}$ ).

\begin{tabular}{|c|c|c|}
\hline Compounds & Formula & Mass Needed, grams \\
\hline $\begin{array}{c}\text { Potassium } \\
\text { Permanganate }\end{array}$ & $\mathrm{KMnO}_{4}$ & 5.52 \\
\hline Water & $\mathrm{H}_{2} \mathrm{O}$ & 100.00 \\
\hline $\begin{array}{c}\text { Manganese Nitrate } \\
\text { Solution } \\
\end{array}$ & $\begin{array}{c}\mathrm{Mn}\left(\mathrm{NO}_{3}\right)_{2}, 50 \mathrm{Wt} \% \\
\text { solution }\end{array}$ & 20.94 \\
\hline Water & $\mathrm{H}_{2} \mathrm{O}$ & 100.00 \\
\hline
\end{tabular}

Add the $\mathrm{KMnO}_{4}$ solution to the mixed $\mathrm{Mn}\left(\mathrm{NO}_{3}\right)_{2}$ vessel at: $0.8 \mathrm{~mL} /$ minute while mixing.

Mix thoroughly. The addition will produce fine black solids which will remain suspended while being agitated.

\section{PART II: $\quad$ Metals Precipitation, Sludge Washing and Thermal Aging}

Next add remaining metal nitrates. 
SRNL-STI-2010-00170

Revision 0

Addition of Metals

\begin{tabular}{|c||c||c|}
\hline \multicolumn{1}{|c||}{ Compounds } & Formula & Mass Needed, grams \\
\hline \hline Ferric Nitrate & $\mathrm{Fe}\left(\mathrm{NO}_{3}\right)_{3} \cdot 9 \mathrm{H}_{2} \mathrm{O}$ & 99.01 \\
\hline \hline Ferric Oxide & $\mathrm{Fe} \mathrm{O}_{3}<5$ micron & 41.58 \\
\hline \hline Nickel Nitrate & $\mathrm{Ni}\left(\mathrm{NO}_{3}\right)_{2} \cdot 6 \mathrm{H}_{2} \mathrm{O}$ & 24.27 \\
\hline \hline Cerium Nitrate & $\mathrm{Ce}\left(\mathrm{NO}_{3}\right)_{3} \cdot 6 \mathrm{H}_{2} \mathrm{O}$ & 1.31 \\
\hline \hline Lanthanum Nitrate & $\mathrm{La}\left(\mathrm{NO}_{3}\right)_{3} \cdot 6 \mathrm{H}_{2} \mathrm{O}$ & 0.78 \\
\hline \hline Silver Nitrate & $\mathrm{AgNO}_{3}$ & 0.047 \\
\hline Cadmium Nitrate & $\mathrm{Cd}\left(\mathrm{NO}_{3}\right)_{2} \cdot 4 \mathrm{H}_{2} \mathrm{O}$ & 0.033 \\
\hline \hline Water & $\mathrm{H}_{2} \mathrm{O}$ & 126.30 \\
\hline
\end{tabular}

Mix until all of the nitrates are dissolved.

Standardize a pH electrode with pH 4, 7 and 10 buffers.

Place the $\mathrm{pH}$ electrode in the precipitation vessel with the metal nitrates and measure and record the $\mathrm{pH}$.

$\mathrm{pH}$

With the nitrate solution agitating, very slowly add $50 \mathrm{wt} \% \mathrm{NaOH}$ at $0.8 \mathrm{~mL} /$ minute until the $\mathrm{pH}$ reaches 10 .

Mass of $50 \mathrm{wt} \% \mathrm{NaOH}$ required will be greater than 80.70 grams

Record mass of 50 wt \% $\mathrm{NaOH}$ used grams

During the precipitation, monitor the temperature and control the addition to keep the temperature below $50{ }^{\circ} \mathrm{C}$.

$\mathrm{pH}$

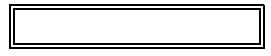

Continue mixing for 1 Hour and then recheck $\mathrm{pH}$.

$\mathrm{pH}$

Allow the slurry to settle overnight or over a weekend.

Decant the supernate from the settled sludge.

\section{Sludge Washing/Settling}

The sludge at this point needs to be washed to remove the excessively high levels of $\mathrm{NO}_{3}{ }^{-}$in the current supernate $\left(\mathrm{NO}_{3}{ }^{-} \sim 1.1\right.$ Molar$)$.

Wash the Settled sludge by batch dilution and gravity settling using $0.001 \mathrm{M} \mathrm{NaOH} / \mathrm{NaNO}_{2}$ wash solutions.

Use a large vessel so that the wash volume is $3 \mathrm{X}$ the settled sludge volume (this minimizes the number of washes).

The washing will require at three or more washing stages. 
Prepare batches of $0.001 \mathrm{M} \mathrm{NaOH}+0.001 \mathrm{M} \mathrm{NaNO}_{2}$ Wash Solution by adding:

\begin{tabular}{|c||c|}
\hline \multicolumn{1}{|c||}{ Compounds } & Grams needed/Liter \\
\hline \hline Sodium Hydroxide & 0.04 \\
\hline \hline Sodium Nitrite & 0.07 \\
\hline \hline Water & 1000 \\
\hline
\end{tabular}

Mix to dissolve to dissolve the salts.

Wash the settled solids with a $0.001 \mathrm{M} \mathrm{NaOH}+0.001 \mathrm{M} \mathrm{NaNO}_{2}$ Wash Solution until the supernate is less than $1000 \mathrm{mg} / \mathrm{L}$ Nitrate.

\section{Thermal Aging the Washed Sludge}

Transfer the sludge slurry to a 2 to 4 Liter reaction kettle with lid, temperature control and condenser to minimize loss of water. Heat the kettle to $95 \mathrm{C}$ for a total of 24 hours while continuously mixing with an overhead mixer.

\section{PART III: Remaining Compounds Addition}

After cooling make the final compounds addition while continuing to mix.

Final Compounds Addition

\begin{tabular}{|c|c|c|}
\hline Compounds & Formula & Mass Needed, grams \\
\hline $\begin{array}{l}\text { Mercuric Nitrate } \\
\text { Monohydrate }\end{array}$ & $\mathrm{Hg}\left(\mathrm{NO}_{3}\right)_{2} \cdot \mathrm{H}_{2} \mathrm{O}$ & 3.31 \\
\hline Sodium Hydroxide & NaOH, 50 wt \% & 13.20 \\
\hline $\begin{array}{l}\text { Alumina } \\
\end{array}$ & $\mathrm{Al}_{2} \mathrm{O}_{3}$ & 2.98 \\
\hline Aluminum Hydroxide & $\mathrm{Al}(\mathrm{OH})_{3}$ & 41.07 \\
\hline Barium Sulfate & $\mathrm{BaSO}_{4}$ & 0.72 \\
\hline "Calcium Carbonate & $\mathrm{CaCO}_{3}$ & 8.25 \\
\hline $\begin{array}{l}\text { Calcium Phosphate } \\
\end{array}$ & $\mathrm{Ca}_{10}(\mathrm{OH})_{2}\left(\mathrm{PO}_{4}\right)_{6}$ & 0.38 \\
\hline Calcium Sulfate & $\mathrm{CaSO}_{4}$ & 0.91 \\
\hline Chromium Oxide & $\mathrm{Cr}_{2} \mathrm{O}_{3}$ & 0.62 \\
\hline Copper Oxide & $\mathrm{CuO}$ & 0.29 \\
\hline $\begin{array}{c}\text { Lithium Hydroxide, } \\
\text { Monohydrate }\end{array}$ & $\mathrm{LiOH} \cdot \mathrm{H}_{2} \mathrm{O}$ & 0.73 \\
\hline Potassium Nitrate & $\mathrm{KNO}_{3}$ & 0.15 \\
\hline Magnesium Oxide & $\mathrm{MgO}$ & 0.35 \\
\hline Sodium Carbonate & $\mathrm{Na}_{2} \mathrm{CO}_{3}$ & 5.00 \\
\hline Sodium Sulfate & $\mathrm{Na}_{2} \mathrm{SO}_{4}$ & 1.10 \\
\hline $\begin{array}{l}\text { Sodium Phosphate } \\
\end{array}$ & $\mathrm{Na}_{3} \mathrm{PO}_{4} \cdot 12 \mathrm{H}_{2} \mathrm{O}$ & 0.23 \\
\hline Sodium Fluoride & $\mathrm{NaF}$ & 0.04 \\
\hline Sodium Chloride & $\mathrm{NaCl}$ & 2.85 \\
\hline Sodium Iodide & $\mathrm{NaI}$ & 0.05 \\
\hline Sodium Nitrite & $\mathrm{NaNO}_{2}$ & 14.95 \\
\hline Sodium Nitrate & $\mathrm{NaNO}_{3}$ & 1.30 \\
\hline Lead Sulfate & $\mathrm{PbSO}_{4}$ & 0.25 \\
\hline
\end{tabular}


SRNL-STI-2010-00170

Revision 0

\begin{tabular}{|c||c||c|}
\hline \multicolumn{1}{|c||}{ Compounds } & Formula & Mass Needed, grams \\
\hline \hline Silica & $\mathrm{SiO}_{2}$ & 2.88 \\
\hline \hline Strontium Carbonate & $\mathrm{SrCO}_{3}$ & 0.25 \\
\hline \hline Zinc Oxide & $\mathrm{ZnO}$ & 0.57 \\
\hline \hline Zirconium Dioxide & $\mathrm{ZrO}_{2}$ & 1.14 \\
\hline
\end{tabular}

Mix the sludge mixture thoroughly for 2 hours then sample and measure density and solids content. 
SRNL-STI-2010-00170

Revision 0

Appendix B: ECC HM Hazardous Sludge Simulant Recipe 


\section{ECC Hazardous HM Sludge Simulant Recipe}

Development of the ECC hazardous HM simulant used reagent grade chemicals and a specific oxide of known particle size. The specific metal oxide is ferric oxide, $<5$ micron, $>99 \%$ purchased from Sigma-Aldrich. Substitutions for this ferric oxide should not be made without additional studies. However, technical grade chemicals may be sufficient for replacing the reagent grade chemicals when producing larger scale quantities of the simulant. These technical grade chemicals should be at least $97 \%$ pure. Care in choosing the technical grade chemicals are necessary to prevent the trace contaminants in the technical grade from swamping the intended concentration of minor waste species.

Many of the salts used in the simulant include waters of hydration and the specific form to be used is shown in the recipe. Care must be taken in storing and using some of these compounds due to their tendency to readily absorb water. Using a salt, which has obviously absorbed excess water, will lead to missing the target value for that compound. When necessary, a solution of the compound can be used. However, the water additions shown in the recipe will have to be appropriately reduced to account for the water in the solution of the compound.

The recipe is formulated below based on production of a one liter quantity of simulant with properties as stated in the body of the report. Larger volumes can be prepared by scaling the chemicals, liquids and vessels in the recipe as needed

\section{ECC Hazardous HM Sludge Simulant Preparation}

Goal: Volume of HM Simulant to be produced

$1,000.0 \mathrm{~mL}$

\section{PART I: Hydrated Manganese Dioxide, $\mathrm{MnO}_{2}$, Preparation}

Add the following to separate vessels: $\left(\mathrm{KMnO}_{4}\right.$ solution will then be fed to the $\mathrm{Mn}\left(\mathrm{NO}_{3}\right)_{2}$ vessel, both at $40^{\circ} \mathrm{C}$ ).

\begin{tabular}{|c|c|c|}
\hline Compounds & Formula & Mass Needed, grams \\
\hline $\begin{array}{c}\text { Potassium } \\
\text { Permanganate }\end{array}$ & $\mathrm{KMnO}_{4}$ & 5.88 \\
\hline Water & $\mathrm{H}_{2} \mathrm{O}$ & 100.00 \\
\hline $\begin{array}{c}\text { Manganese Nitrate } \\
\text { Solution } \\
\end{array}$ & $\begin{array}{c}\mathrm{Mn}\left(\mathrm{NO}_{3}\right)_{2}, 50 \mathrm{Wt} \% \\
\text { solution }\end{array}$ & 20.97 \\
\hline Water & $\mathrm{H}_{2} \mathrm{O}$ & 100.00 \\
\hline
\end{tabular}

Add the $\mathrm{KMnO}_{4}$ solution to the mixed $\mathrm{Mn}\left(\mathrm{NO}_{3}\right)_{2}$ vessel at: $0.83 \mathrm{~mL} / \mathrm{minute}$ while mixing.

Mix thoroughly. The addition will produce fine black solids which will remain suspended while being agitated.

\section{PART II: $\quad$ Metals Precipitation + Heat Treatment}

Add to the vessel containing the Part I solution plus $\mathrm{MnO}_{2}$ precipitate:

DI Water $\quad \mathrm{H}_{2} \mathrm{O} \quad 150.00$ grams 
Then add the following compounds to the vessel (100 g DI water is available for rinsing as indicated at the end of the table):

\begin{tabular}{|c|c|c|}
\hline Compounds & Formula & Mass Needed, grams \\
\hline Ferric Nitrate & $\mathrm{Fe}\left(\mathrm{NO}_{3}\right)_{3} \cdot 9 \mathrm{H}_{2} \mathrm{O}$ & 0.000 \\
\hline $\begin{array}{l}\text { Ferric Oxide } \\
\end{array}$ & $\mathrm{Fe}_{2} \mathrm{O}_{3}<5$ micron & 7.489 \\
\hline Nickel Nitrate & $\mathrm{Ni}\left(\mathrm{NO}_{3}\right)_{2} \cdot 6 \mathrm{H}_{2} \mathrm{O}$ & 3.115 \\
\hline $\begin{array}{l}\text { Zirconyl nitrate } \\
\end{array}$ & $\mathrm{ZrO}\left(\mathrm{NO}_{3}\right)_{2} \cdot \mathrm{xH}_{2} \mathrm{O}, \mathrm{x} \sim 6$ & 0.857 \\
\hline Cerium nitrate & $\mathrm{Ce}\left(\mathrm{NO}_{3}\right)_{3} \cdot 6 \mathrm{H}_{2} \mathrm{O}$ & 0.341 \\
\hline Lanthanum nitrate & $\mathrm{La}\left(\mathrm{NO}_{3}\right)_{3} \cdot 6 \mathrm{H}_{2} \mathrm{O}$ & 0.180 \\
\hline Barium Nitrate & $\mathrm{Ba}\left(\mathrm{NO}_{3}\right)_{2}$ & 0.848 \\
\hline $\begin{array}{l}\text { Calcium Nitrate } \\
\end{array}$ & $\mathrm{Ca}\left(\mathrm{NO}_{3}\right)_{2} \cdot 4 \mathrm{H}_{2} \mathrm{O}$ & 6.790 \\
\hline $\begin{array}{l}\text { Cupric Nitrate } \\
\end{array}$ & $\mathrm{Cu}\left(\mathrm{NO}_{3}\right)_{2} \cdot 2.5 \mathrm{H}_{2} \mathrm{O}$ & 0.192 \\
\hline $\begin{array}{l}\text { Magnesium Nitrate } \\
\end{array}$ & $\mathrm{Mg}\left(\mathrm{NO}_{3}\right)_{2} \cdot 6 \mathrm{H}_{2} \mathrm{O}$ & 11.604 \\
\hline $\begin{array}{c}\text { Lead Nitrate } \\
\end{array}$ & $\mathrm{Pb}\left(\mathrm{NO}_{3}\right)_{2}$ & 0.293 \\
\hline Zinc Nitrate & $\mathrm{ZZn}\left(\mathrm{NO}_{3}\right)_{2} \cdot 6 \mathrm{H}_{2} \mathrm{O}$ & 0.334 \\
\hline $\begin{array}{l}\text { Silver Nitrate } \\
\end{array}$ & $\mathrm{AgNO}_{3}$ & 0.050 \\
\hline Neodymium Nitrate & $\mathrm{Nd}\left(\mathrm{NO}_{3}\right)_{3} \cdot 6 \mathrm{H}_{2} \mathrm{O}$ & 0.084 \\
\hline Cadmium Nitrate & $\mathrm{Cd}\left(\mathrm{NO}_{3}\right)_{2} \cdot 4 \mathrm{H}_{2} \mathrm{O}$ & 0.035 \\
\hline Strontium Nitrate & $\mathrm{Sr}\left(\mathrm{NO}_{3}\right)_{2}$ & 0.087 \\
\hline $\begin{array}{l}\text { Chromium Nitrate } \\
\end{array}$ & $\mathrm{C} \mathrm{Cr}\left(\mathrm{NO}_{3}\right)_{3} \cdot 9 \mathrm{H}_{2} \mathrm{O}$ & 3.457 \\
\hline Sodium Nitrate & $\mathrm{NaNO}_{3}$ & 14.423 \\
\hline Boric Acid & $\mathrm{H}_{3} \mathrm{BO}_{3}$ & 0.270 \\
\hline Sodium Fluoride & $\mathrm{NaF}$ & 0.238 \\
\hline Sodium Chloride & $\mathrm{NaCl}$ & 0.517 \\
\hline Sodium Sulfate & $\mathrm{Na}_{2} \mathrm{SO}_{4}$ & 2.561 \\
\hline Sodium Phosphate & $\mathrm{Na}_{3} \mathrm{PO}_{4} \cdot 12 \mathrm{H}_{2} \mathrm{O}$ & 0.403 \\
\hline Potassium Molybdate & $\mathrm{K}_{2} \mathrm{MoO}_{4}$ & 0.060 \\
\hline $\begin{array}{c}\text { Rinse Water } \\
\end{array}$ & $\mathrm{H}_{2} \mathrm{O}$ & 100.00 \\
\hline
\end{tabular}

All the compounds should completely dissolve.

Standardize a pH electrode with pH 4, 7 and 10 buffers.

Place the $\mathrm{pH}$ electrode in the precipitation vessel with the metal nitrates and measure the $\mathrm{pH}$.

$\mathrm{pH}$

With the nitrate solution agitating, slowly add 28.78 grams of $\mathrm{NaOH}$ (50 wt \%) grams of $\mathrm{NaOH}(50 \mathrm{wt} \%$ ) actually added.

Planned Addition Rate $0.75 \mathrm{~mL} / \mathrm{min}$ for batch precipitation. Approximate Feed time will be 38.4 minutes.

Note that the $\mathrm{pH}$ after addition will be $>13$.

$\mathrm{pH}$

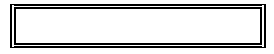

Continue mixing for 30 minutes and then recheck $\mathrm{pH}$. 
Add the following species to allow generation of aluminosilicates during heat treatment.

\begin{tabular}{|c||c||c|}
\hline Compounds & Formula & Mass Needed, grams \\
\hline \hline Sodium Aluminate & $\mathrm{NaAlO}_{2}$ & 11.30 \\
\hline \hline Sodium Metasilicate & $\mathrm{Na}_{2} \mathrm{SiO}_{3} \cdot 9 \mathrm{H}_{2} \mathrm{O}$ & 2.1202 \\
\hline \hline Rinse Water & $\mathrm{H}_{2} \mathrm{O}$ & 25.00 \\
\hline
\end{tabular}

\section{Heat Treatment Process}

Transfer the slurry to a 2 to 4 Liter reaction kettle with lid, temperature control and condenser to minimize loss of water. Heat the kettle to $95 \mathrm{C}$ for a total of 24 hours while continuously mixing with an overhead mixer.

\section{PART III: Remaining Salts Addition}

Next add while mixing

\begin{tabular}{|c||c|c|}
\hline \multicolumn{1}{|c||}{ Compounds } & Formula & Mass Needed, grams \\
\hline \hline Sodium Oxalate & $\mathrm{Na}_{2} \mathrm{C}_{2} \mathrm{O}_{4}$ & 0.33 \\
\hline \hline Sodium Carbonate & $\mathrm{Na}_{2} \mathrm{CO}_{3}$ & 87.98 \\
\hline \hline Sodium Nitrite & $\mathrm{NaNO}_{2}$ & 8.59 \\
\hline \hline Rinse Water & $\mathrm{H}_{2} \mathrm{O}$ & 50.00 \\
\hline
\end{tabular}

Thoroughly mix the slurry for at least 30 minutes to insure good mixing and complete dissolution of the added salts.

Check pH of the slurry.

$\mathrm{pH}$

\section{PART IV: Base-Reactive Insoluble Solids Addition}

Add the final insoluble compounds listed below to the simulated sludge while maintaining complete mixing.

Final Insoluble Compounds Addition

\begin{tabular}{|c||c||c||}
\hline Compounds & Formula & Mass Needed, grams \\
\hline \hline Alumina & $\mathrm{Al}_{2} \mathrm{O}_{3}$ & 90.08 \\
\hline Aluminum Hydroxide & $\mathrm{Al}(\mathrm{OH})_{3}$ & 0.00 \\
\hline Titanium dioxide & $\mathrm{TiO}_{2}$ & 0.025 \\
\hline \hline Rinse \& Final Water & $\mathrm{H}_{2} \mathrm{O}$ & 264.26 \\
\hline
\end{tabular}

Mix thoroughly for 30 minutes.

Allow the slurry to settle for at least one night.

The settled sludge volume should be about $30 \%$ of the total volume. 
Decant the clear supernate to remove between 50 and $60 \%$ of the original volume without removing any insoluble sludge solids.

Measure either the decanted supernate volume or the decanted supernate mass and density and calculate the volume.

Decanted Supernate Volume $\mathrm{mL}$

Now add the same volume of DI water to the simulant.

DI Water Added $\mathrm{mL}$

Mix the slurry for one hour and allow settling overnight.

The settled sludge volume should again be about $30 \%$ of the total volume.

Decant the clear first wash supernate to remove between 50 and $60 \%$ of the original volume without removing and insoluble sludge solids.

Measure either the decanted first wash supernate volume or the decanted first wash supernate mass and density and calculate the volume.

Decanted first wash Volume $\mathrm{mL}$

Now add the same volume of DI water to the simulant.

DI Water Added $\mathrm{mL}$

Mix the diluted sludge simulant for one hour then proceed to Part V: Final Additions.

\section{Part V: Final Additions}

Add the following compounds while mixing.

\begin{tabular}{|c||c||c|}
\hline Compounds & Formula & Mass Needed, grams \\
\hline \hline $\begin{array}{c}\text { Mercuric Nitrate } \\
\text { Monohydrate }\end{array}$ & $\mathrm{Hg}\left(\mathrm{NO}_{3}\right)_{2} \cdot \mathrm{H}_{2} \mathrm{O}$ & 3.49 \\
\hline \hline Sodium Hydroxide & $\mathrm{NaOH}, 50 \mathrm{wt} \%$ & 1.63 \\
\hline $\begin{array}{c}\text { Lithium Hydroxide, } \\
\text { Monohydrate }\end{array}$ & $\mathrm{LiOH} \cdot \mathrm{H}_{2} \mathrm{O}$ & 0.78 \\
\hline \hline Rinse Water & $\mathrm{H}_{2} \mathrm{O}$ & 50.00 \\
\hline
\end{tabular}

Mix the final simulant for one hour and then collect a sample and measure the solids content (Total, Insoluble Soluble) and the simulant density. 
SRNL-STI-2010-00170

Revision 0

Appendix C: ECC Blend Hazardous Sludge Simulant Recipe 


\section{ECC Blend (Purex+HM) Hazardous Sludge Simulant Recipe}

Development of the ECC hazardous Blend simulant used reagent grade chemicals and a specific oxide of known particle size. The specific metal oxide is ferric oxide, $<5$ micron, $>99 \%$ purchased from Sigma-Aldrich. Substitutions for this ferric oxide should not be made without additional studies. However, technical grade chemicals may be sufficient for replacing the reagent grade chemicals when producing larger scale quantities of the simulant. These technical grade chemicals should be at least $97 \%$ pure. Care in choosing the technical grade chemicals are necessary to prevent the trace contaminants in the technical grade from swamping the intended concentration of minor waste species.

Many of the salts used in the simulant include waters of hydration and the specific form to be used is shown in the recipe. Care must be taken in storing and using some of these compounds due to their tendency to readily absorb water. Using a salt, which has obviously absorbed excess water, will lead to missing the target value for that compound. When necessary, a solution of the compound can be used. However, the water additions shown in the recipe will have to be appropriately reduced to account for the water in the solution of the compound.

The recipe is formulated below based on production of a one liter quantity of simulant with properties as stated in the body of the report. Larger volumes can be prepared by scaling the chemicals, liquids and vessels in the recipe as needed

\section{ECC Hazardous Blend Sludge Simulant Preparation}

Goal: Volume of Blend Simulant to be produced

$1,000.0 \mathrm{~mL}$

\section{PART I: Hydrated Manganese Dioxide, $\mathrm{MnO}_{2}$, Preparation}

Add the following to separate vessels: $\left(\mathrm{KMnO}_{4}\right.$ solution will then be fed to the $\mathrm{Mn}\left(\mathrm{NO}_{3}\right)_{2}$ vessel, both at $40^{\circ} \mathrm{C}$ ).

\begin{tabular}{|c|c|c|}
\hline Compounds & Formula & Mass Needed, grams \\
\hline $\begin{array}{c}\text { Potassium } \\
\text { Permanganate }\end{array}$ & $\mathrm{KMnO}_{4}$ & 5.70 \\
\hline Water & $\mathrm{H}_{2} \mathrm{O}$ & 75 \\
\hline $\begin{array}{c}\text { Manganese Nitrate } \\
\text { Solution }\end{array}$ & $\begin{array}{c}\mathrm{Mn}\left(\mathrm{NO}_{3}\right)_{2}, 50 \mathrm{Wt} \% \\
\text { solution }\end{array}$ & 21.59 \\
\hline 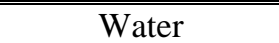 & $2 \mathrm{H}_{2} \mathrm{O}$ & 50.0 \\
\hline
\end{tabular}

Add the $\mathrm{KMnO}_{4}$ solution to the mixed $\mathrm{Mn}\left(\mathrm{NO}_{3}\right)_{2}$ vessel at: $0.83 \mathrm{~mL} / \mathrm{minute}$ while mixing.

Mix thoroughly. The addition will produce fine black solids which will remain suspended while being agitated.

\section{PART II: $\quad$ Metals Precipitation + Heat Treatment}

Next add the following compounds to the vessel (75 grams DI water is available for rinsing as indicated at the end of the table): 
SRNL-STI-2010-00170

Revision 0

\begin{tabular}{|c|c|c||}
\hline \multicolumn{1}{|c|}{ Compounds } & Formula & Mass Needed, grams \\
\hline \hline Ferric Nitrate & $\mathrm{Fe}\left(\mathrm{NO}_{3}\right)_{3} \cdot 9 \mathrm{H}_{2} \mathrm{O}$ & 92.41 \\
\hline \hline Ferric Oxide & $\mathrm{Fe} \mathrm{O}_{3}<5$ micron & 38.81 \\
\hline \hline Nickel Nitrate & $\mathrm{Ni}\left(\mathrm{NO}_{3}\right)_{2} \cdot 6 \mathrm{H}_{2} \mathrm{O}$ & 22.72 \\
\hline \hline Cerium Nitrate & $\mathrm{Ce}\left(\mathrm{NO}_{3}\right)_{3} \cdot 6 \mathrm{H}_{2} \mathrm{O}$ & 0.34 \\
\hline \hline Lanthanum Nitrate & $\mathrm{La}\left(\mathrm{NO}_{3}\right)_{3} \cdot 6 \mathrm{H}_{2} \mathrm{O}$ & 0.18 \\
\hline \hline Neodymium nitrate & $\mathrm{Nd}\left(\mathrm{NO}_{3}\right)_{3} \cdot 6 \mathrm{H}_{2} \mathrm{O}$ & 0.08 \\
\hline \hline Silver Nitrate & $\mathrm{AgNO}_{3}$ & 0.05 \\
\hline \hline Calcium Nitrate & $\mathrm{Ca}\left(\mathrm{NO}_{3}\right)_{2} \cdot 4 \mathrm{H}_{2} \mathrm{O}$ & 22.52 \\
\hline \hline Cadmium Nitrate & $\mathrm{Cd}\left(\mathrm{NO}_{3}\right)_{2} \cdot 4 \mathrm{H}_{2} \mathrm{O}$ & 0.03 \\
\hline \hline Copper Nitrate & $\mathrm{Cu}\left(\mathrm{NO}_{3}\right)_{2} \cdot 2 \cdot 5 \mathrm{H}_{2} \mathrm{O}$ & 0.83 \\
\hline \hline Potassium Nitrate & $\mathrm{KNO}_{3}$ & 0.56 \\
\hline \hline Magnesium Nitrate & $\mathrm{Mg}\left(\mathrm{NO}_{3}\right)_{2} \cdot 6 \mathrm{H}_{2} \mathrm{O}$ & 7.75 \\
\hline \hline Strontium nitrate & $\mathrm{Sr}_{(}\left(\mathrm{NO}_{3}\right)_{2}$ & 0.62 \\
\hline \hline Zinc Nitrate & $\mathrm{Zn}\left(\mathrm{NO}_{3}\right)_{2} \cdot 6 \mathrm{H}_{2} \mathrm{O}$ & 2.00 \\
\hline \hline Sodium Sulfate & $\mathrm{Na}_{2} \mathrm{SO}_{4}$ & 3.81 \\
\hline \hline Sodium Phosphate & $\mathrm{Na}_{3} \mathrm{PO}_{4} \cdot 12 \mathrm{H}_{2} \mathrm{O}$ & 2.90 \\
\hline \hline Sodium Fluoride & $\mathrm{NaF}_{1}$ & 0.36 \\
\hline \hline Sodium Chloride & $\mathrm{NaCl}_{3}$ & 6.46 \\
\hline \hline Sodium Nitrate & $\mathrm{NaNO}_{3}$ & 0.00 \\
\hline \hline Boric Acid & $\mathrm{H}_{3} \mathrm{BO}_{3}$ & 0.27 \\
\hline \hline Potassium Molybdate & $\mathrm{K}_{2} \mathrm{MoO}_{4}$ & 0.06 \\
\hline \hline Water & $\mathrm{H}_{2} \mathrm{O}$ & 75.00 \\
\hline \hline
\end{tabular}

Mix until all of the nitrates are dissolved.

Standardize a pH electrode with pH 4, 7 and 10 buffers.

Place the $\mathrm{pH}$ electrode in the precipitation vessel with the metal nitrates and measure and record the $\mathrm{pH}$.

$\mathrm{pH}$

With the nitrate solution agitating, very slowly add $50 \mathrm{wt} \% \mathrm{NaOH}$ at $0.7 \mathrm{~mL} /$ minute until the $\mathrm{pH}$ reaches 10 .

Mass of 50 wt \% NaOH required may be greater than 101.90 grams

Record mass of 50 wt \% NaOH used grams

During the precipitation, monitor the temperature and control the addition to keep the temperature below $50{ }^{\circ} \mathrm{C}$.

$\mathrm{pH}$

Continue mixing for 1 Hour and then recheck $\mathrm{pH}$.

$\mathrm{pH}$

Add the following species to allow generation of aluminosilicates during heat treatment. 


\begin{tabular}{||c||c||c||}
\hline Compounds & Formula & Mass Needed, grams \\
\hline $\begin{array}{c}\text { Sodium } \\
\text { Aluminate }\end{array}$ & $\mathrm{NaAlO}_{2}$ & 17.35 \\
\hline $\begin{array}{c}\text { Sodium } \\
\text { Metasilicate }\end{array}$ & $\mathrm{Na}_{2} \mathrm{SiO}_{3} \cdot 5 \mathrm{H}_{2} \mathrm{O}$ & 17.71 \\
\hline \hline Water & $\mathrm{H}_{2} \mathrm{O}$ & 75.00 \\
\hline
\end{tabular}

\section{Heat Treatment Process}

Transfer the slurry to a 2 to 4 Liter reaction kettle with lid, temperature control and condenser to minimize loss of water. Heat the kettle to $95 \mathrm{C}$ for a total of 24 hours while continuously mixing with an overhead mixer.

\section{PART III: Base Reactive Compounds Addition}

Next add while mixing.

\begin{tabular}{|c||c||c||}
\hline \multicolumn{1}{|c||}{ Compounds } & Formula & Mass Needed, grams \\
\hline \hline Alumina & $\mathrm{Al}_{2} \mathrm{O}_{3}$ & 63.95 \\
\hline \hline Aluminum Hydroxide & $\mathrm{Al}(\mathrm{OH})_{3}$ & 10.87 \\
\hline \hline Barium Sulfate & $\mathrm{BaSO}_{4}$ & 0.73 \\
\hline \hline Chromium Oxide & $\mathrm{Cr}_{2} \mathrm{O}_{3}$ & 0.64 \\
\hline \hline Sodium Oxalate & $\mathrm{Na}_{2} \mathrm{C}_{2} \mathrm{O}_{4}$ & 0.45 \\
\hline \hline Sodium Carbonate & $\mathrm{Na}_{2} \mathrm{CO}_{3}$ & 41.94 \\
\hline \hline Sodium Nitrite & $\mathrm{NaNO}_{2}$ & 11.58 \\
\hline \hline Lead Sulfate & $\mathrm{PbSO}_{4}$ & 0.26 \\
\hline \hline Titanium Oxide & $\mathrm{TiO}_{2}$ & 0.03 \\
\hline \hline Zirconium Dioxide & $\mathrm{ZrO}_{2}$ & 1.15 \\
\hline \hline Water & $\mathrm{H}_{2} \mathrm{O}$ & 408.92 \\
\hline
\end{tabular}

Mix thoroughly for 30 minutes.

Allow the slurry to settle for at least one night.

The settled sludge volume should be about $30-40 \%$ of the total volume.

Decant the clear supernate to remove between 50 and $60 \%$ of the original volume without removing any insoluble sludge solids.

Measure either the decanted supernate volume or the decanted supernate mass and density and calculate the volume.

Decanted Supernate Volume $\square \mathrm{mL}$

Now add the same volume of DI water to the simulant.

DI Water Added $\mathrm{mL}$

Mix the slurry for one hour and allow settling overnight. 
The settled sludge volume should again be about $30-40 \%$ of the total volume.

Decant the clear first wash supernate to remove between 50 and $60 \%$ of the original volume without removing and insoluble sludge solids.

Measure either the decanted first wash supernate volume or the decanted first wash supernate mass and density and calculate the volume.

Decanted first wash Volume $\mathrm{mL}$

Now add the same volume of DI water to the simulant.

DI Water Added $\mathrm{mL}$

Mix the diluted sludge simulant for one hour then proceed to Part V: Final Additions.

\section{Part IV: Final Additions}

Add the following compounds while mixing.

\begin{tabular}{|c||c||c|}
\hline \multicolumn{1}{|c||}{ Compounds } & Formula & Mass Needed, grams \\
\hline \hline Mercuric Nitrate Monohydrate & $\mathrm{Hg}\left(\mathrm{NO}_{3}\right)_{2} \cdot \mathrm{H}_{2} \mathrm{O}$ & 3.43 \\
\hline \hline Sodium Hydroxide, 50 wt \% & $\mathrm{NaOH}, 50 \mathrm{wt} \%$ & 13.27 \\
\hline \hline $\begin{array}{c}\text { Lithium Hydroxide } \\
\text { Monohydrate }\end{array}$ & $\mathrm{LiOH} . \mathrm{H}_{2} \mathrm{O}$ & 0.76 \\
\hline \hline Water & $\mathrm{H}_{2} \mathrm{O}$ & 50.0 \\
\hline
\end{tabular}

Mix the final simulant for one hour and then collect a sample and measure the solids content (Total, Insoluble, and Soluble) and the simulant density. 


\section{Distribution:}
A. B. Barnes, 999-W
D. A. Crowley, 773-43A
S. D. Fink, 773-A
B. J. Giddings, 786-5A
C. C. Herman, 999-W
S. L. Marra, 773-A
A. M. Murray, 773-A
F. M. Pennebaker, 773-42A
J. H. Scogin, 773-A
W. R. Wilmarth, 773-A
C. J. Martino, 773-42A
M. S. Hay, 773-42A
W. D. King, 773-42A
M. R. Poirier, 773-42A
M. R. Williams, 786-5A
N. R. Davis, 704-26F
R. H. Spires, 704-26F
E. T. Ketusky, 704-70F
T. M. Punch, 704-71F
G. D. Thaxton, 704-70F
T. H. Huff, 704-71F
J. R. Vitale, 704-70F
C. B. Sudduth, 704-71F
K. J. Bumpus, 730-2B 